(C) 2018, The Authors. Published by FASS Inc. and Elsevier Inc. on behalf of the American Dairy Science Association ${ }^{\circledR}$.

This is an open access article under the CC BY-NC-ND license (http://creativecommons.org/licenses/by-nc-nd/4.0/).

\title{
Short-term methane emissions from 2 dairy farms in California estimated by different measurement techniques and US Environmental Protection Agency inventory methodology: A case study
}

\author{
C. Arndt, ${ }^{* 1}$ A. B. Leytem,† A. N. Hristov,‡ D. Zavala-Araiza,§ J. P. Cativiela,\# S. Conley,Il C. Daube,đ \\ I. Faloona,II and S. C. Herndonף \\ ${ }^{*}$ Environmental Defense Fund, San Francisco, CA 94105 \\ †USDA-Agricultural Research Service, Northwest Irrigation and Soils Research Laboratory, Kimberly, ID 83341 \\ fDepartment of Animal Science, The Pennsylvania State University, University Park 16802 \\ §Environmental Defense Fund, Austin, TX 78701 \\ \#Dairy Cares, Sacramento, CA 95814 \\ IIDepartment of Land, Air, and Water Resources, University of California, Davis 95616 \\ TAerodyne Research Inc., Billerica, MA, 01821
}

\section{ABSTRACT}

Reported estimates of $\mathrm{CH}_{4}$ emissions from ruminants and manure management are up to 2 times higher in atmospheric top-down calculations than in bottom-up (BU) inventories. We explored this discrepancy by estimating $\mathrm{CH}_{4}$ emissions of 2 dairy facilities in California with US Environmental Protection Agency (US EPA) methodology, which is used for BU inventories, and 3 independent measurement techniques: (1) open-path measurements with inverse dispersion modeling (hereafter open-path), (2) vehicle measurements with tracer flux ratio method, and (3) aircraft measurements with the closed-path method. All 3 techniques were used to estimate whole-facility $\mathrm{CH}_{4}$ emissions during 3 to $6 \mathrm{~d}$ per farm in the summer of 2016. In addition, open-path was used to estimate whole-facility $\mathrm{CH}_{4}$ emissions over 13 to $14 \mathrm{~d}$ per farm in the winter of 2017 . Our objectives were to (1) compare whole-facility $\mathrm{CH}_{4}$ measurements utilizing the different measurement techniques, (2) compare whole-facility $\mathrm{CH}_{4}$ measurements to US EPA inventory methodology estimates, and (3) compare $\mathrm{CH}_{4}$ emissions between 2 dairies. Whole-facility $\mathrm{CH}_{4}$ estimates were similar among measurement techniques. No seasonality was detected for $\mathrm{CH}_{4}$ emissions from animal housing, but $\mathrm{CH}_{4}$ emissions from liquid manure storage were 3 to 6 times greater during the summer than during the winter measurement periods. The findings confirm previous studies showing that whole-facility $\mathrm{CH}_{4}$ emissions need to be measured throughout the year to estimate and evaluate annual inventories. Open-path measurements for liquid manure storage emissions were similar to monthly US EPA estimates during the summer, but

Received September 22, 2017.

Accepted August 11, 2018.

${ }^{1}$ Corresponding author: claudia.arndt@catie.ac.cr not during the winter measurement periods. However, the numerical difference was relatively small considering yearly emission estimates. Manure $\mathrm{CH}_{4}$ emissions contributed 69 to $79 \%$ and 26 to $47 \%$ of whole-facility $\mathrm{CH}_{4}$ emissions during the summer and winter measurement periods, respectively. Methane yields from animal housing were similar between farms (on average 20.9 $\mathrm{g}$ of $\mathrm{CH}_{4} / \mathrm{kg}$ of dry matter intake), but $\mathrm{CH}_{4}$ emissions normalized by volatile solids (VS) loading from liquid manure storage (g of $\mathrm{CH}_{4}$ per day/kg of VS produced by all cattle per day) at 1 dairy were 1.7 and 3.5 times greater than at the other during the summer (234 vs. $137 \mathrm{~g}$ of $\mathrm{CH}_{4} / \mathrm{kg}$ of VS) and winter measurement periods ( 78 vs. $22 \mathrm{~g}$ of $\mathrm{CH}_{4} / \mathrm{kg}$ of VS), respectively. We attributed much of this difference to the proportion of manure stored in liquid (anaerobic) form, and suggest that manure management practices that reduce the amount of manure solids stored in liquid form could significantly reduce dairy $\mathrm{CH}_{4}$ emissions.

Key words: methane, measurement technique, emission, manure

\section{INTRODUCTION}

Reducing short-lived climate pollutants is key to limiting global warming to $2^{\circ} \mathrm{C}$ above preindustrial levels (Shindell et al., 2012). Methane is a short-lived climate pollutant with 3 times the global warming potential (84 vs. 28$)$ in the short term (20 yr) than the long term (100 yr; IPCC, 2013). Consequently, the contribution of $\mathrm{CH}_{4}$ to anthropogenic greenhouse gas is greater in the short term than in the long term (28 vs. $11 \%$; US EPA, 2017b). Livestock alone contribute 35\% [9.3 million metric tonnes (MMT) of $\mathrm{CH}_{4}$, with $72 \%$ from enteric fermentation and $28 \%$ from manure management] of the anthropogenic $\mathrm{CH}_{4}$ in the United States (US EPA, 2017b). In California, the largest dairy-producing state 
with $19 \%$ of the total US milk production (USDA-ERS, 2017), the California Air Resource Board (CARB, 2017) estimates that dairy livestock alone contributes $55 \%$ (0.7 MMT of $\mathrm{CH}_{4}$, with $45 \%$ from enteric fermentation and $55 \%$ from manure management) of the anthropogenic $\mathrm{CH}_{4}$ emissions. The CARB (2017) estimates are bottom-up estimates and based on US EPA (2017a) methodology (Deshpande et al., 2014), which is derived from the Intergovernmental Panel on Climate Change (IPCC, 2006b) guidelines for emissions from livestock and manure management.

Regional top-down (TD) measurements, which used inverse modeling to attribute $\mathrm{CH}_{4}$ emissions to different emission sources, have suggested that the national and California inventories underestimate $\mathrm{CH}_{4}$ emissions from livestock (Miller et al., 2013; Wecht et al., 2014a; Bergamaschi et al., 2015; Jeong et al., 2016; Cui et al., 2017). Based on long-term measurements, Miller et al. (2013) estimated that national $\mathrm{CH}_{4}$ emissions from ruminants and manure management are up to 2 times greater than the US Environmental Protection Agency (EPA) inventory estimates. Similarly, long-term measurements by Jeong et al. (2016) estimated that $\mathrm{CH}_{4}$ emissions from dairy livestock in the San Joaquin Valley are 2 times greater than the California Air Resource Board (CARB) estimates. Short-term measurements by Trousdell et al. (2016) and Cui et al. (2017) estimated that $\mathrm{CH}_{4}$ emissions from dairy livestock in the San Joaquin Valley are up to 2.4 times greater than CARB estimates. Other regional short-term TD measurements have suggested that dairy livestock emissions are similar to CARB estimates (Peischl et al., 2013; Wecht et al., 2014b). Top-down inventory estimates are based on inverse modeling and use gridded bottom-up (BU) inventories as prior estimates. Thus, errors associated with gridded BU inventories can lead to errors in the TD inventory (Hristov et al., 2017); this makes TD estimates not ideal to evaluate US EPA methodology. Measurements of facilities that provide activity and management data avoid this potential error, and thus are more suited to evaluate US EPA methodology. Open-path has been used to estimate emissions from dairy facilities for many years, and more recently vehicle- and aircraft-based techniques have become available. It is important to evaluate these different techniques because $\mathrm{CH}_{4}$ measurements are needed to not only evaluate US EPA methodology because of the discrepancy in TD and US EPA inventories, but also to estimate reduction potentials of mitigation strategies. This is even more important in California, after the California Legislature passed Senate Bill 1383 (State of California, 2016) in September 2016, which requires CARB to adopt regulations to reduce $\mathrm{CH}_{4}$ emissions from dairy manure management by up to $40 \%$ below the dairy sector's 2013 levels by 2030 .

As $\mathrm{CH}_{4}$ emissions from dairy farms come from 2 main sources, enteric fermentation and manure storage [primarily liquid (anaerobic) manure storage], it is important to distinguish between the 2 sources to validate US EPA methodology and to estimate their contributions to the current $\mathrm{CH}_{4}$ inventories. The objectives of our study were to (1) compare whole-facility $\mathrm{CH}_{4}$ measurements utilizing different measurement techniques, (2) compare whole-facility $\mathrm{CH}_{4}$ measurements to US EPA inventory methodology estimates, and (3) compare $\mathrm{CH}_{4}$ emissions between 2 dairies.

\section{MATERIALS AND METHODS}

Whole-facility $\mathrm{CH}_{4}$ emissions were measured at 2 commercial dairy farms (dairy 1 and 2) in California. Each farm was visited once in summer 2016 and once in winter 2017. On dairy 1, emissions were measured from June 24 to 30 (summer 2016) and from January 17 to February 1 (winter 2017). On dairy 2, emissions were measured from June 20 to 23 (summer 2016) and from February 2 to 16 (winter 2017). During the summer measurement period, 3 independent techniques were used to measure emissions: (1) open-path measurements with inverse dispersion modeling (hereafter open-path); (2) vehicle measurements with tracer flux ratio method (vehicle); and (3) aircraft measurements with a closed-path (elliptical) method (aircraft). During the winter measurement period, only open-path measurements were conducted.

\section{Farm Selection}

The dairy farms were selected based on facility layout (separation of animal housing and liquid manure storage system), layout relative to downwind roads, distance to other $\mathrm{CH}_{4}$ sources, and owner willingness to participate in the study. On both farms, the animal housing was in the southern part of the facility and the manure storage system (settling basins and anaerobic lagoon) was in the northern part of the facility (Figures 1 and 2). Both dairies were surrounded by irrigated cropland on 4 sides and located in areas with no known close $\mathrm{CH}_{4}$ sources; the nearest expected $\mathrm{CH}_{4}$ source, such as another dairy or oil and gas facility, was more than $2.5 \mathrm{~km}$ away from each dairy.

\section{Farm Management}

Both farms had Jersey cattle as the primary breed. The California Department of Food and Agriculture (CDFA) estimated that in California, in 2016, Jersey 
and mixed herds produced 10.2 and $11.6 \%$ of California's milk, respectively (CDFA, 2017).

Dairy 1 had 6,036 cattle (54\% dairy cows, $37 \%$ replacement heifers, and 10\% calves; Table 1) and cows were milked twice daily. During the measurement periods (summer 2016 and winter 2017), average DMI was $20.0 \pm 0.1$ and average milk production was 27.4 $\pm 0.2 \mathrm{~kg} /$ lactating cow per day (mean $\pm \mathrm{SD}$ ). Replacement heifers and dairy cows were fed TMR starting at $0500 \mathrm{~h}$ and continued until $1600 \mathrm{~h}$; replacement heifers and nonlactating cows were fed once daily (morning) and lactating cows were fed twice daily (morning and afternoon).

The dairy cows (lactating and dry cows) and latepregnant heifers were housed in freestall barns with and without dry lot access on the western part of the facility, whereas replacement heifers and older calves were housed in dry lots on the eastern part of the facility. Dairy cows had no access to adjacent dry lots when the lots were muddy due to high precipitation during
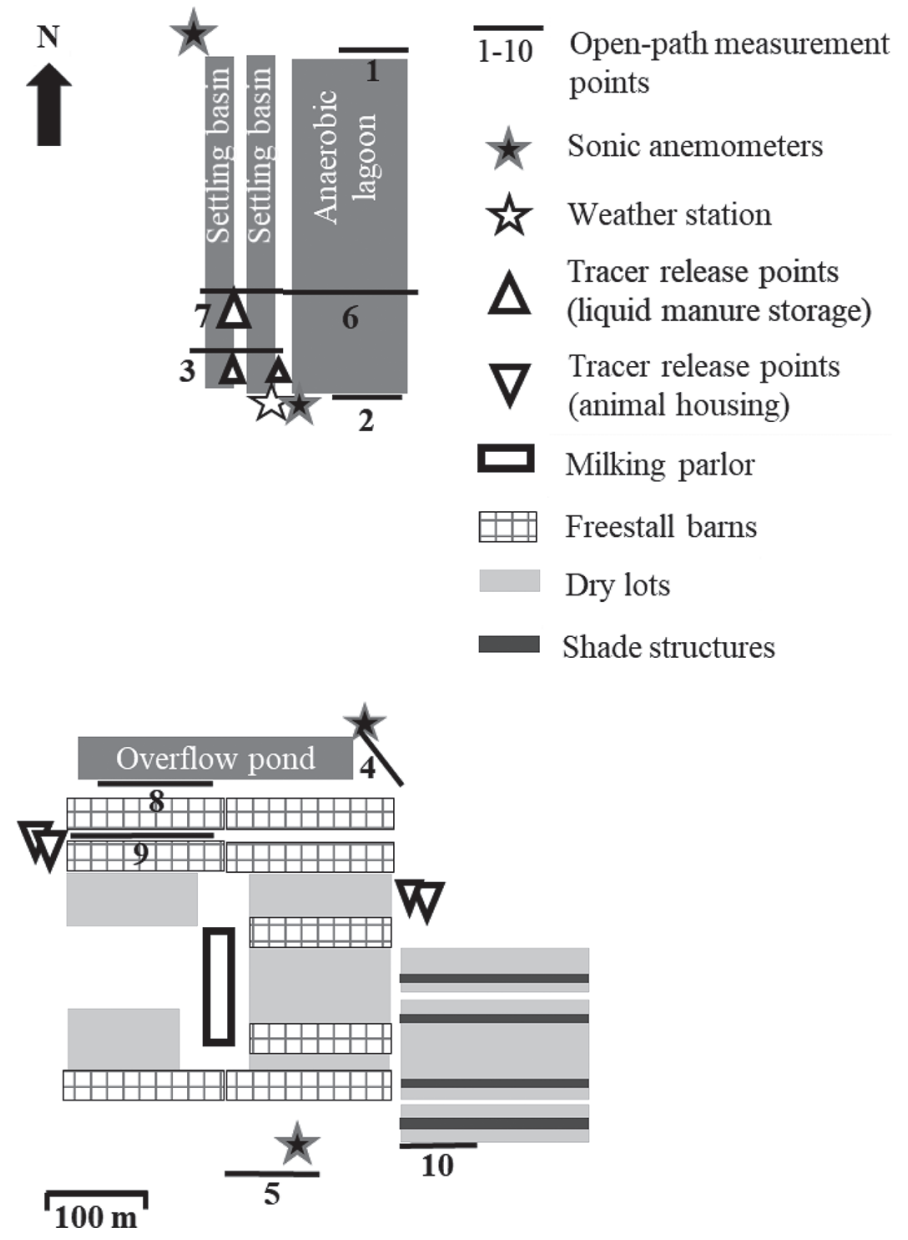

Figure 1. Facility layout, open-path measurement, and tracer release points for vehicle measurements on dairy 1. the winter months. The stalls in the barns were bedded with dried manure solids [2.5 to $3.0 \mathrm{~kg}$ of volatile solids (VS)/dairy cow per day], which is a common practice for dairies in California. During winter, when precipitation was high, approximately twice the amount of bedding was used to keep the stalls dry. The farm had run out of manure solids to use for bedding by January 17, 2017; thus, rice hulls (8.2 t/d on a DM basis) were used for bedding instead of manure solids during the winter open-path measurement period (between January 17 and February 1, 2017). Manure solids for bedding were recovered from scraping the dry lots (every 2 wk when the lots were dry) and evacuating the crust on the settling basins (every May and October, except for October 2016). Recovered manure solids were exclusively used for bedding.

Manure and bedding were removed from the freestall barns and the feed alleys of the dry lots by flushing twice a day. Recycled anaerobic lagoon water was used for flushing. The wash water from the milking parlor went straight into the liquid manure storage. Two sequential parallel settling basins (each $9,464 \mathrm{~m}^{2}$ surface

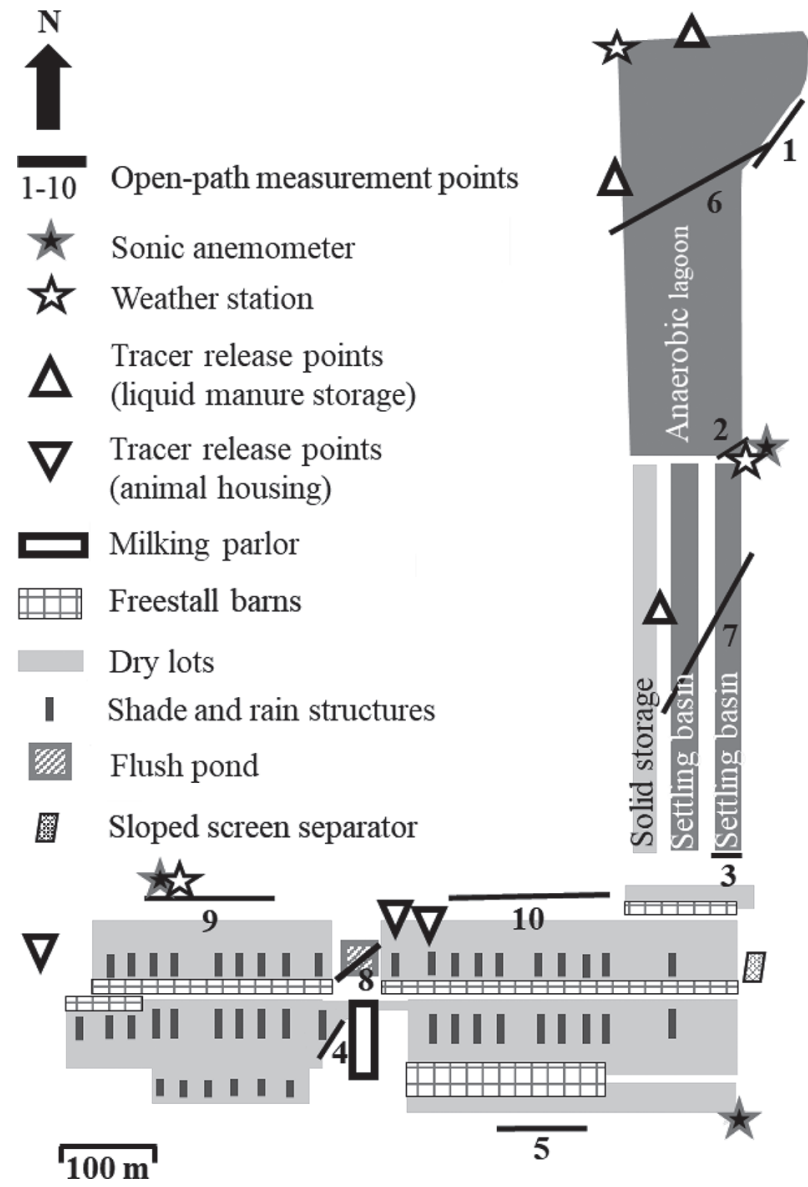

Figure 2. Facility layout, open-path measurement, and tracer release points for vehicle measurements on dairy 2 . 
Table 1. Characteristics of dairy 1 and dairy 2

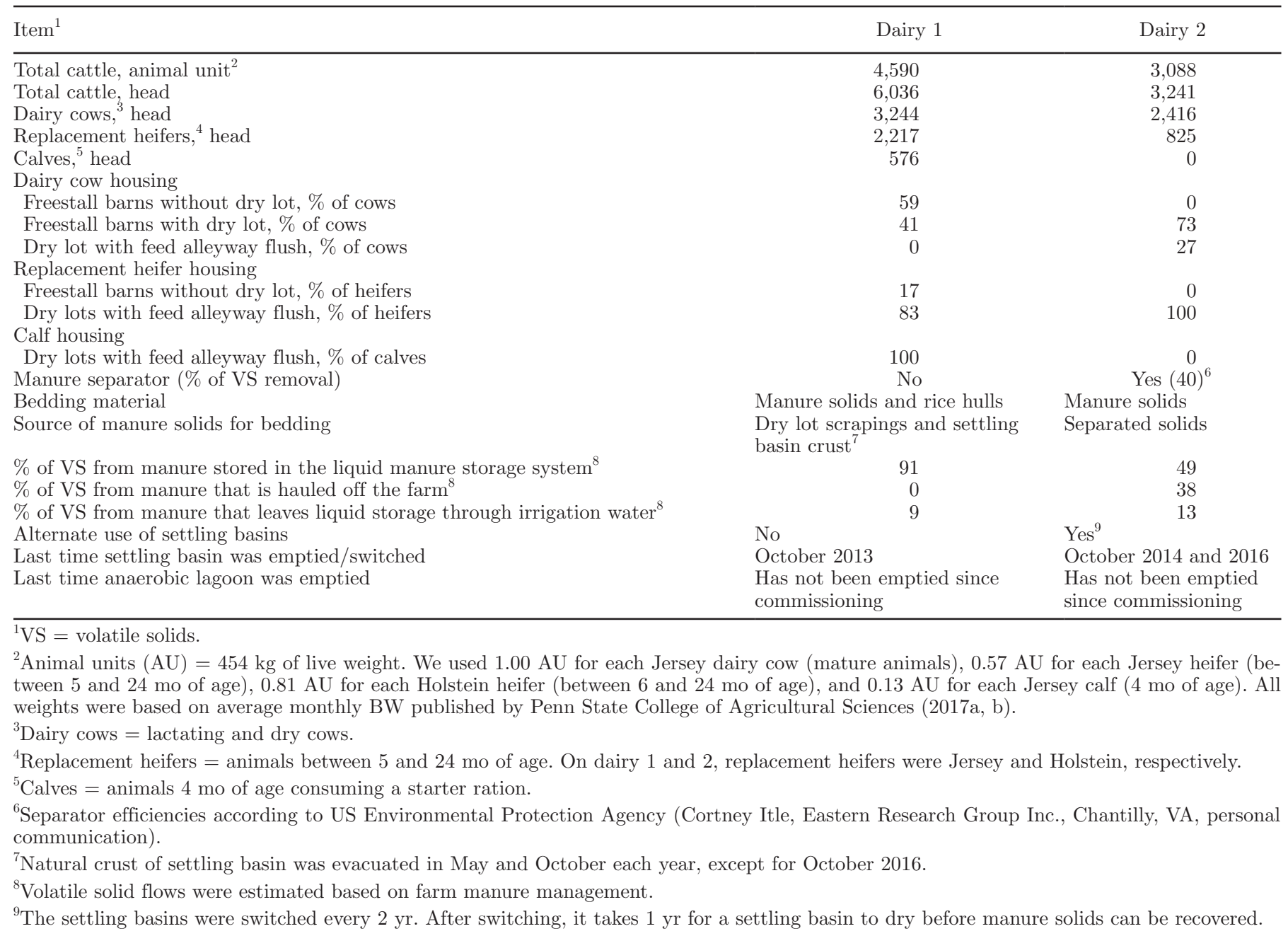

area) and 1 anaerobic lagoon $\left(40,560 \mathrm{~m}^{2}\right.$ surface area) were used for liquid manure storage. The anaerobic lagoon water was used to irrigate the surrounding fields when needed. Thus, the lagoon water level was higher during the winter (rainy season) and lower during the summer (dry season) due to water demand of the crops on the surrounding fields. However, despite the use of lagoon water for irrigation, the liquid manure storage system had not been completely emptied since commissioning ( $>5$ yr). Supplemental File S1 (https://doi .org/10.3168/jds.2017-13881) provides further details on facility layouts and management practices.

Dairy 2 had 3,241 cattle ( $75 \%$ dairy cows, $25 \%$ replacement heifers, and $0 \%$ calves; Table 1). Holstein heifers were reared on-site and moved to a different facility before calving, whereas Jersey replacement heifers and calves were reared offsite and moved back to dairy 2 before calving. Cows were milked twice daily. During the measurement periods (summer 2016 and winter 2017), average DMI was $20.8 \pm 0.7$ and aver- age milk production was $26.5 \pm 0.3 \mathrm{~kg} /$ lactating cow per day (mean $\pm \mathrm{SD}$ ). Similar to dairy 1, replacement heifers and dairy cows were fed TMR starting at 0500 $\mathrm{h}$ and continuing until $1600 \mathrm{~h}$; replacement heifers and nonlactating cows were fed once daily (morning) and lactating cows were fed twice daily (morning and afternoon).

The dairy cows were housed in freestall barns with dry lot access and in dry lots. The replacement heifers were housed in dry lots. Stalls in the barns were bedded with dried manure solids (2.5 to $3.0 \mathrm{~kg}$ of VS/dairy cow per day). During winter, approximately 1.5 to 2 times the amount of bedding was used to keep the stalls dry. Similar to dairy 1, cows housed in barns had no access to adjacent dry lots when the lots were muddy due to high precipitation during the winter months. Manure solids were recovered by scraping the dry lots, emptying dried settling basins, and the use of a sloped-screen manure separator that removed solids from the flush water from the barns and dry lot alleys. The farm used 
$90 \%$ of the manure solids recovered by the sloped-screen manure separator for bedding, whereas the remaining manure solids were hauled off the farm to be used as fertilizer elsewhere.

Manure and bedding were removed from the freestall barns and the feed alleys of the dry lots by flushing twice a day. The wash water from the milking parlor was collected in a flush pond north of the milking parlor $\left(1,823 \mathrm{~m}^{2}\right.$ surface area; Figure 2$)$ and later used for flushing the barns and feed alleys of the dry lots. Two parallel settling basins $\left(9,068 \mathrm{~m}^{2}\right.$ surface area to the east and $10,256 \mathrm{~m}^{2}$ surface area to the west) and an anaerobic lagoon $\left(65,424 \mathrm{~m}^{2}\right.$ surface area) were used for liquid manure storage (Figure 2); only 1 of the settling basins was used at a time. After one had been used for approximately $2 \mathrm{yr}$, it was left to dry and accumulated manure solids were removed while the other settling basin was used. The settling basins were alternated in October 2014 and 2016. The anaerobic lagoon water was used to irrigate the surrounding fields when needed. Thus, similar to dairy 1 , lagoon water level was higher during the winter (rainy season) and lower during the summer (dry season) due to the water demand of the crops on the surrounding fields. Similar to dairy 1 , the anaerobic lagoon had not been completely emptied since commissioning ( $>5 \mathrm{yr}$ ). Supplemental File S1 (https://doi.org/10.3168/jds.2017-13881) provides further details on facility layouts and management practices and Table 1 summarizes the characteristics of dairy 1 and 2 .

\section{Sampling of Feed, Manure, and Bedding}

The amount of TMR offered (on an as-fed basis) and diet DM used by the farm to formulate rations were recorded during each measurement period. In addition, all TMR loads were sampled according to Robinson and Meyer (2010), and samples were stored at $-20^{\circ} \mathrm{C}$ until analysis. During the summer measurement period, daily samples of each TMR load were collected from June 25 to 27 and June 21 to 23 on dairy 1 and 2, respectively. During the winter measurement period, samples of each TMR load were collected on January 18 and 26 and on February 3 and 9 on dairy 1 and 2, respectively. On dairy 1, refused feed was also collected, weighed, and sampled during the summer (on June 25 and 29) but not during the winter measurement period. On dairy 2 , all cattle were fed at $0 \%$ refusals during the summer and winter measurement periods.

Lagoon samples were taken during the summer measurement periods and used to determine the VS removed in lagoon water used for irrigation. Approximately 7 to 8 samples $(500 \mathrm{~mL})$ were collected around the perimeter of the anaerobic lagoons at a depth of approximately $0.6 \mathrm{~m}$ using a pole with retractable lid. Samples were frozen at $-20^{\circ} \mathrm{C}$ until analysis. Bedding was sampled from stockpiled material during the winter measurement period. Approximately 8 subsamples were composited and frozen $\left(-20^{\circ} \mathrm{C}\right)$; frozen lagoon and bedding samples were shipped to the USDA-ARS laboratory in Kimberly, Idaho, for analysis.

\section{Sample Analysis}

Samples from individual TMR loads and refused feed were composited across days by farm on an equalweight basis (as fed). Composited TMR, refused feed, and bedding samples were dried at $55^{\circ} \mathrm{C}$ (forced-air oven) for $72 \mathrm{~h}$ and ground to pass through a $2-\mathrm{mm}$ Wiley mill screen (Thomas Scientific, Swedesboro, NJ). Samples of ground TMR and refused feed were shipped to Dairyland Laboratories Inc. (Acardia, WI), where they were analyzed for DM content, ash, CP, ash-free neutral detergent fiber (aNDF), and ether extract. Details on the individual analysis procedures can be found in Supplemental File S2 (https://doi.org/10 .3168/jds.2017-13881). An average value from samples that have been run at Dairyland Laboratories was used to estimate neutral detergent insoluble $\mathrm{CP}$ of the TMR. Nonfiber carbohydrates were calculated according to (NRC, 2001) using CP, aNDF, neutral detergent insoluble CP, ether extract, and ash. Gross energy of the TMR was calculated using heat of combustion of $4.2 \mathrm{Mcal} / \mathrm{kg}$ for carbohydrates (aNDF and NFC), $5.6 \mathrm{Mcal} / \mathrm{kg}$ for $\mathrm{CP}$, and $9.4 \mathrm{Mcal} / \mathrm{kg}$ for fatty acids (estimated by ether extract - 1; Maynard et al., 1979; Allen, 2000). Bedding and anaerobic lagoon samples were analyzed for VS according to standard method 2540E (Eaton et al., 2005).

\section{Volatile Solids Production and Flow Rates}

The VS excreted by the different cattle types [dairy calves (4 mo of age), replacement heifers ( $>4$ mo of age), and dairy cows (lactating and dry cows)] were estimated based on US EPA (2017a) methodology using the measured DMI and the calculated GE content of the diet. Details of the calculation can be found in Supplemental File S3 (https://doi.org/10.3168/jds .2017-13881).

Volatile solids were stored dry (dry lot and solid storage) and in liquid (liquid manure storage system). On dairy 1, the liquid storage system consisted of 2 settling basins, an anaerobic lagoon, and an overflow pond. The overflow pond was only used during winter 2017 due to record-high precipitation in California during the winter of 2016 and 2017. On dairy 2, the liquid storage system consisted of a flush pond, manure separator, 
2 alternately used settling basins, and an anaerobic lagoon. The proportion of VS stored in the dry and liquid system was calculated based on US EPA (2017a) assumptions, which included the removal of $40 \% \mathrm{VS}$ from the flush water by the manure separator before entering the anaerobic lagoon on dairy 2 (Cortney Itle, Eastern Research Group Inc., Chantilly, VA, personal communication), and on-farm practices (Table 2). The on-farm VS flows were estimated because US EPA (2017a) assumptions did not reflect on-farm manure management practices of the measured dairies. On dairy 1 , all VS from manure entered the liquid manure storage system either as manure or bedding (manure solid) because dairy 1 did not haul manure off the farm. The only VS that left the liquid manure storage on dairy 1 were the VS that were pumped out of the anaerobic lagoon as part of the irrigation water. On dairy 2, the on-farm VS flow of manure and bedding to the liquid manure system was determined from the amount and composition of manure solids that were used for bedding, the percentage of recovered VS used for bedding (90\% of the manure solids recovered by the manure separator were used for bedding), and the efficiency of the manure separator (40\%). In addition, similar to dairy 1, VS left the liquid manure storage as part of the irrigation water. According to the producer on dairy 1 , approximately 95 million $\mathrm{L}$ of anaerobic lagoon water was used to irrigate the surrounding fields during the 2016 growing season. On dairy 2, the irrigation water used over the growing season was estimated to be equal to the amount of wash water produced in the milking parlor and from the sprinklers in the concrete holding pen outside of the milking parlor ( $\sim 110$ million L). No records of the timing of irrigation events or the amount of water used during each irrigating event were available. Irrigation would have been scheduled based on evapotranspiration of the crops over the growing season and therefore vary depending on crop growth and weather. Due to this lack of data, we assumed a daily use of irrigation water in our calculation. The amount of VS flow from the irrigation water was estimated by multiplying the amount of irrigation water by the VS content of the part of the anaerobic lagoon in which the irrigation pumps were located. For dairy 1 and 2, the VS content was 8,158 and 7,824 $\mathrm{mg}$ of VS /L, respectively. A detailed description of the on-farm manure flows can be found in Supplemental File S4 (https://doi .org/10.3168/jds.2017-13881).

\section{Calculation of Intake and $\mathrm{CH}_{4}$ Emissions}

Enteric $\mathrm{CH}_{4}$ emissions were estimated following the US EPA (2017a) methodology using observed DMI and dietary GE content. Details on the calculation can be found in Supplemental File S5 (https://doi.org/10 $.3168 /$ jds.2017-13881). The $95 \%$ confidence interval (CI) of the enteric $\mathrm{CH}_{4}$ emissions ( -11 and $\left.+18 \%\right)$ were obtained from Table A-280 (US EPA, 2017a).

Manure $\mathrm{CH}_{4}$ emissions from liquid manure storage (settling basins, anaerobic lagoon, overflow pond, and flush pond) were calculated on a monthly basis following US EPA (2017a) methodology. For both dairies, $\mathrm{CH}_{4}$ emissions from liquid manure storage were estimated using the US EPA (2017a) methodology for anaerobic lagoons because US EPA (2017a) assumes that dairies that use flush systems, such as dairy 1 and 2 , manage the collected manure in anaerobic lagoons. We computed $\mathrm{CH}_{4}$ emissions from liquid storage for VS flow rates based on US EPA (2017a) assumptions as well as on-farm practices. The $95 \% \mathrm{CI}$ of the $\mathrm{CH}_{4}$ emissions from anaerobic lagoons $(-18$ and $+20 \%)$ were obtained from Table A-280 (USEPA, 2017a). For more details on the calculation see Supplemental File S5.

\section{Methane Emission Measurements}

For both dairies, ambient air temperature and relative humidity were measured on site during the monitoring period (measurements made at 15-min intervals), whereas precipitation data were retrieved from California weather databases hosted on the University of California Agriculture and Natural Resources website (UC-IPM, 2017) using a California Irrigation Management Information System station within $5 \mathrm{~km}$ of each dairy farm.

During the summer measurement period on dairy 1, the prevailing wind was from the south between 1200 and $1600 \mathrm{~h}$ and from the north between 1600 and 1200 h. The ambient temperature was $24.6 \pm 8.1^{\circ} \mathrm{C}$ (mean $\pm \mathrm{SD}$ ), the wind speed was $3.0 \pm 1.5 \mathrm{~m} / \mathrm{s}$, the relative humidity was $49.8 \pm 23.2 \%$, and precipitation was 0 $\mathrm{mm}$. During the winter measurement period, the prevailing wind was from the south or north depending on the day. The ambient temperature was $7.8 \pm 2.8^{\circ} \mathrm{C}$, the wind speed was $4.3 \pm 2.3 \mathrm{~m} / \mathrm{s}$, the relative humidity was $86.1 \pm 11.3 \%$, and it rained for 6 of the $15 \mathrm{~d}$ of measurements (every day from Jan 20 to 26 ) with a total precipitation of $93 \mathrm{~mm}$ over the monitoring period.

During the summer measurement period on dairy 2, the prevailing wind was from the north-northwest. The ambient temperature was $26.7 \pm 6.8^{\circ} \mathrm{C}$ (mean $\pm \mathrm{SD}$ ), the wind speed was $3.0 \pm 1.5 \mathrm{~m} / \mathrm{s}$, the relative humidity was $27.5 \pm 14.5 \%$, and precipitation was $0 \mathrm{~mm}$. During the winter measurement period, the prevailing wind was from the south and north or north-northwest depending on the day. The ambient temperature was $13.9 \pm 3.0^{\circ} \mathrm{C}$, the wind speed was $2.9 \pm 2.0 \mathrm{~m} / \mathrm{s}$, the relative humidity was $90.0 \pm 9.2 \%$, and it rained for 
6 of the $16 \mathrm{~d}$ of measurements (February 2, 3, 6, 7, 9, and 10) with a total precipitation of $38 \mathrm{~mm}$ over the monitoring period.

\section{Open-Path Measurements with Inverse Dispersion Modeling}

The Northwest Irrigation and Soils Research Laboratory (Kimberly, ID) of the USDA Agricultural Research Service conducted ground measurements using open-path Fourier transform infrared spectrometry coupled with inverse dispersion modeling to estimate $\mathrm{CH}_{4}$ emission rates. On-farm measurement locations are indicated for dairy 1 and dairy 2 in Figure 1 and Figure 2, respectively. These locations were chosen to acquire separate measurements of the $\mathrm{CH}_{4}$ emissions from discrete sources (animal housing, settling basin, anaerobic lagoon, overflow pond, and flush pond). Measurement dates and $\mathrm{CH}_{4}$ emissions $(\mathrm{kg} / \mathrm{d}$ ) for each location can be found in Supplemental Table S1 (https:// doi.org/10.3168/jds.2017-13881). The concentration of $\mathrm{CH}_{4}$ was measured using open-path Fourier transform infrared spectrometry (Air Sentry, Cerex Monitoring Solutions, Atlanta, GA, and ABB-Bomem MB-100, MDA, Atlanta, GA; Griffiths et al., 2009; Shao et al., 2010). Spectra were acquired continuously and averaged over 5-min intervals. Background concentrations were measured at each dairy before the onset of the study as well as at a remote (nonagricultural affected) location for comparison. Experiments performed with the open-path units demonstrated that background concentrations were stable and did not fluctuate. In

Table 2. United States Environmental Protection Agency (EPA; US EPA, 2017a) manure management assumptions compared with on-farm manure management practices on dairy 1 and 2

\begin{tabular}{|c|c|}
\hline US EPA assumptions & On-farm practices \\
\hline $\begin{array}{l}\text { Dry lots are not a manure management system for } \\
\text { dairy cows }\end{array}$ & $\begin{array}{l}30 \% \text { of dairy cows were managed in dry lots on dairy } 1 \text {, and } \geq 40 \% \text { of cows had } \\
\text { access to dry lots on both dairies }\end{array}$ \\
\hline $\begin{array}{l}\text { Anaerobic lagoons are not a manure management } \\
\text { system for replacement heifers }\end{array}$ & $\begin{array}{l}13 \text { to } 100 \% \text { of replacement heifer manure was captured by flush water and entered } \\
\text { the liquid manure storage system }\end{array}$ \\
\hline Calf manure management is not accounted for & $\begin{array}{l}13-100 \% \text { of calf manure was captured by flush water and entered the liquid manure } \\
\text { storage system on dairy } 1^{5}\end{array}$ \\
\hline Does not account for the use of bedding & $100 \%$ of bedding was captured by the flush ${ }^{6}$ \\
\hline $\begin{array}{l}\text { Evacuation of natural crusts on liquid storage is not } \\
\text { part of the manure management system }\end{array}$ & Evacuation of natural crust of settling basins on dairy 1 \\
\hline $\begin{array}{l}\text { Removal of VS from liquid storage by irrigation } \\
\text { water is unaccounted for }\end{array}$ & 9 to $13 \%$ of excreted VS were removed from liquid storage by irrigation water ${ }^{7}$ \\
\hline $\begin{array}{l}\text { Assumes complete emptying of anaerobic lagoon } \\
\text { once per year in October }\end{array}$ & Anaerobic lagoons have not been emptied since commissioning \\
\hline \multicolumn{2}{|c|}{$\begin{array}{l}{ }^{1} \text { Assumes that dairy cows spend at least } 6.6 \mathrm{~h} / \mathrm{d} \text { in areas that collect manure in liquid form, calculated as } 2.5 \mathrm{~h} / \mathrm{d} \text { milking (personal communica- } \\
\text { tion with farmer) plus } 4.1 \pm 0.2 \mathrm{~h} / \mathrm{d} \text { (mean } \pm \mathrm{SD} \text { ) spent feeding according to Grant (2009), Legrand et al. (2009), and Gomez and Cook (2010). } \\
{ }^{2} \mathrm{VS}=\text { volatile solids. } \\
{ }^{3} \text { Cortney Itle, Eastern Research Group Inc., Chantilly, VA, personal communication. } \\
{ }^{4} \text { Assumes that replacement heifers spend at least } 3.1 \mathrm{~h} \text { in the feed alleyway that collects manure in liquid form. Heifers spend } 3.1 \pm 0.1 \mathrm{~h} / \mathrm{d} \\
\text { (mean } \pm \mathrm{SD} \text { ) feeding according to Greter et al. (2008), DeVries and von Keyserlingk (2009), and Greter et al. (2012). } \\
{ }^{5} \text { Assumes that calves spend the same amount of time in the feed alley as replacement heifers. } \\
{ }^{6} \text { Between } 2.5 \text { and } 3.0 \mathrm{~kg} \text { of VS/dairy cow per day were added as bedding during dry weather conditions (summer) and between } 1.5 \text { and } 2.0 \text { times } \\
\text { that during wet weather conditions (winter). }\end{array}$} \\
\hline
\end{tabular}


addition, the on-farm concentration data at each location was filtered for wind direction to isolate times when no upwind source of $\mathrm{CH}_{4}$ was present to verify that background concentrations were consistent over time. Quantitative determinations of $\mathrm{CH}_{4}$ concentrations were performed by partial least squares regression of the open-path Fourier transform infrared spectra (Griffiths et al., 2009; Shao et al., 2010), and the detection limit of $\mathrm{CH}_{4}$ was less than 0.01 ppmv (parts per million by volume). Concentration data were processed to produce 15 -min average mixing-ratio concentrations at the source areas $(\boldsymbol{C})$.

The wind environment at the dairy was described by simple Monin-Obukhov similarity theory relationships defined by $u^{*}, L, z_{0}$, and $\beta$, as provided by 3 -dimensional sonic anemometers (RM Young Model 81000 ultrasonic anemometer, Traverse City, MI), where $u^{*}$ is the friction velocity, $L$ is the Obukhov stability length, $z_{0}$ is the surface roughness length, and $\beta$ is wind direction [see Flesch et al. (2004) for details of how these parameters were calculated from a sonic anemometer]. The sonic anemometer was placed on top of a 3-m tower at each location, where there were minimal flow disturbances from structures upwind, to capture a more idealized wind flow of the area, as suggested by Flesch et al. (2005). Wind parameters were calculated for each 15min period (corresponding to $C$ observations). Methane concentrations and on-site barometric pressure, humidity, air temperature, wind direction, and wind speed were used to calculate $\mathrm{CH}_{4}$ emissions for each 15-min interval, which is described in Supplemental File S6 (https://doi.org/10.3168/jds.2017-13881).

Methane emissions from all liquid storage facilities on dairy 1 (settling basins, anaerobic lagoon, and overflow pond) and dairy 2 (settling basins, anaerobic lagoon, and flush pond) were added together and reported as liquid manure storage to compare with liquid manure storage emissions estimated by US EPA methods for anaerobic lagoons. The 95\% CI was determined using a bootstrapping method that resampled (with replacement) the distribution of each measurement by measurement location (housing area, settling basins, anaerobic lagoon, overflow pond, and flush pond) 10,000 times (Efron and Tibshirani, 1993).

\section{Vehicle Measurements with Tracer Flux Ratio Method}

Aerodyne Research Inc. conducted ground measurements employing the tracer flux ratio (TFR) method (Lamb et al., 1995; Mønster et al., 2014; Roscioli et al., 2015) using a mini Aerodyne Mobile Laboratory (Herndon et al., 2005). Details on the mobile labora- tory setup can be found in Supplemental File S7 and Supplemental Figure S1 (https://doi.org/10.3168/jds .2017-13881). Mixing ratios of various species were measured every second using 3 Aerodyne single-laser quantum cascade laser spectrometers $\left[\mathrm{CH}_{4}\right.$, acetylene $\left(\mathrm{C}_{2} \mathrm{H}_{2}\right)$, and ethane $\left.\left(\mathrm{C}_{2} \mathrm{H}_{6}\right)\right]$ and a nondispersive infrared LI-6262 gas analyzer $\left(\mathrm{CO}_{2}\right.$ and $\left.\mathrm{H}_{2} \mathrm{O}\right)$ from LI-COR Biosciences Inc. (Lincoln, NE). Additional details of the measurement systems and analysis protocols are described in Supplemental File S7. Site-wide emissions were quantified using TFR measurements. Analysis of the relative correlation with dual tracers during the TFR measurements was used to apportion the $\mathrm{CH}_{4}$ burden from the 2 major sources of $\mathrm{CH}_{4}$ : animal housing and liquid manure storage. Tracer gases $\left(\mathrm{C}_{2} \mathrm{H}_{2}\right.$ and $\mathrm{C}_{2} \mathrm{H}_{6}$ ) were placed strategically near individual sources (Figures 1 and 2) and released at rates ranging from 10 to $40 \mathrm{~L} / \mathrm{min}$. Using a different tracer near each emission source offered spatial distinction in real-time, with the goal of having tracer gas and $\mathrm{CH}_{4}$ merge together. Optimal placement of tracers depended on wind conditions, site access and road access. Vehicle transects occurred on public roads downwind of each site at various distances (up to $6 \mathrm{~km}$ away). Transects used to distinguish the relative contributions of individual sources within dairy farms were typically closer than whole-facility transects, except for the settling basin on dairy 2. The close-in transects at the dairy farms involved additional uncertainty. The tracer was released at a single point, but the housing and liquid manure storage areas, the main subjects of this study, were distributed over tens or hundreds of meters. For TFR to effectively quantify area emissions with a point source release, the molar ratio of emissions to tracer must be conducted sufficiently downwind for co-dispersion to be met. Effectively, when doing the close-in transects, the method is susceptible to spatial mismatch between emissions and tracer plumes. The effect of this spatial mismatch is reduced as the transect downwind distance increases.

At dairy 2, low wind speeds and poor road access limited the quality of data for certain sections of the farm. No TFR plumes were captured for the anaerobic lagoon area during attempted close-in transects on June 21. The settling basin estimate from dairy 2 involved analysis of distant plumes by determining a fraction of each tracer's overlap with the overall $\mathrm{CH}_{4}$ plume (dual-sum method). This fraction was applied to the average whole-site $\mathrm{CH}_{4}$ plumes on dairy 2 to deliver an emission estimate of the settling basin. Supplemental Table S2 (https://doi.org/10.3168/jds.2017-13881) includes details on source area, date, times, number of plumes, and downwind distances of vehicle-based mea- 
surements at dairy 1 and 2. Supplemental Figure S2 (https://doi.org/10.3168/jds.2017-13881) provides an example of real-time results during a transect at dairy 2. Supplemental Figure S3 (https://doi.org/10.3168/ jds.2017-13881) displays enhancements of tracer gas and target $\mathrm{CH}_{4}$ emissions measured along various roads from $\sim 0.8$ to $6.0 \mathrm{~km}$ away from dairy 2 . With increasing distance, tracer plumes more closely simulate the site emission plumes. Ideally, 2 tracers would be used to model a single source (to provide an internal data quality indicator), but given the presence of multiple area sources on each dairy, a single tracer was used to overlap with each source.

Uncertainties were expressed as 95\% CI of the pool of valid plume intercepts. Plumes, defined as enhancements of $\mathrm{CH}_{4}, \mathrm{C}_{2} \mathrm{H}_{2}$, and $\mathrm{C}_{2} \mathrm{H}_{6}$, were validated by applying acceptance criteria described in Supplemental File S7 and Figure S7 (https://doi.org/10.3168/jds .2017-13881). Essentially, this was done by comparing the downwind molar ratio of the 2 tracers to the ratio of their known flow rates. For hours containing fewer than 2 data points, method-based factor errors derived from a previous study (Roscioli et al., 2015) were employed to calculate an upper and lower $95 \%$ confidence limit. Applied to this work, these hourly averages were assigned upper and lower limit error factors of 1.85 to 0.53 , respectively. For example, an hourly averaged $\mathrm{CH}_{4}$ emission of $100 \mathrm{~kg} / \mathrm{h}$ would be bounded by 185 to $53 \mathrm{~kg} / \mathrm{h}$ at $95 \%$ confidence.

\section{Aircraft Measurements with Closed-Path Method}

The University of California, Davis, and Scientific Aviation Inc. (Boulder, CO) conducted the airborne $\mathrm{CH}_{4}$ measurements of the dairies using a series of concentric, closed flight paths around the facilities. Emission rates were estimated by applying Gauss's Theorem (Conley et al., 2017). To summarize the method, the aircraft flew a series of concentric closed paths around the source, measuring $\mathrm{CH}_{4}$ mixing ratio, pressure, temperature, and horizontal wind (vector components). Using pressure and temperature, the $\mathrm{CH}_{4}$ mixing ratio was converted to a $\mathrm{CH}_{4}$ density $\left(\mathrm{kg} / \mathrm{m}^{3}\right)$, which was then multiplied by the wind speed to achieve a $\mathrm{CH}_{4}$ flux vector. The instantaneous flux into the closed path was the dot product of the $\mathrm{CH}_{4}$ flux vector and the unit normal to the flight path. Next, the normal components of the $\mathrm{CH}_{4}$ flux were summed around the closed path to yield the net flux per unit altitude entering the closed path. Each closed path was then summed in the vertical to yield the total net flux into the volume inscribed by the flight path. As the volume is bounded by the earth's surface at the bottom and the flight path includes altitudes above the level of the plume, the net flux into the volume can be assumed equal to the source strength.

A total of 5 measurements (between 1100 and 1900 h) were conducted at dairy 1 and a total of 6 measurements (between 1130 and $1800 \mathrm{~h}$ ) were conducted at dairy 2. Specifics for each of the flights can be found in Supplemental Table S3 (https://doi.org/10.3168/jds .2017-13881) and an example of the laps for afternoon flight at dairy 2 is provided in Supplemental Figure S4 (https://doi.org/10.3168/jds.2017-13881).

\section{Comparison Among Measurement Techniques}

Unlike the automatic daily emissions readings of open-path, both vehicle and aircraft measurements were not continuous and required the engagement of a research team during measurements. Furthermore, the aircraft measurements were limited to daytime because the boundary layer collapses at night, precluding flight at the appropriate altitude. Due to budget constraints, $\mathrm{CH}_{4}$ measurements by the vehicle and aircraft technique were limited to 10 and $4 \mathrm{~h}$ per day, respectively. We extrapolated their hourly emissions to daily emissions by multiplying the hourly emissions by 24 to compare them with open-path measurements, which measured emissions over a $24-\mathrm{h}$ period. This extrapolation is not ideal, as there can be diurnal fluctuations in emissions; however, it was the only method available to normalize the data for comparison. Uncertainties of each measurement technique were expressed as 95\% CI. Statistical significance $(P \leq 0.05)$ was declared when the $95 \%$ CI of 2 measurements did not overlap.

\section{RESULTS AND DISCUSSION}

\section{All Measurement Techniques Estimated Similar Whole-Facility $\mathrm{CH}_{4}$ Emissions}

Whole-facility $\mathrm{CH}_{4}$ emissions estimated by the different measurement techniques (open-path, vehicle, and aircraft) were not different within each farm $(P>0.05$; Figure 3). During the summer measurement periods, on-farm emission estimates among all measurement techniques ranged between 6,985 and $7,219 \mathrm{~kg}$ of $\mathrm{CH}_{4} / \mathrm{d}$ and between 3,046 and $3,715 \mathrm{~kg}$ of $\mathrm{CH}_{4} / \mathrm{d}$ for dairy 1 and 2, respectively. The uncertainties associated with open-path, vehicle, and aircraft measurements on dairy $1( \pm 9, \pm 9$, and $\pm 22 \%$, respectively) and $2( \pm 11, \pm 27$, and $\pm 25 \%$, respectively) were greater than the variation among measurement techniques. Table 3 summarizes the characteristics of the measurement techniques. Hourly open-path estimates for the dairy cow housing (dairy 1) combined over 9 consecutive days during the winter measurements showed $\mathrm{CH}_{4}$ emission peaks af- 


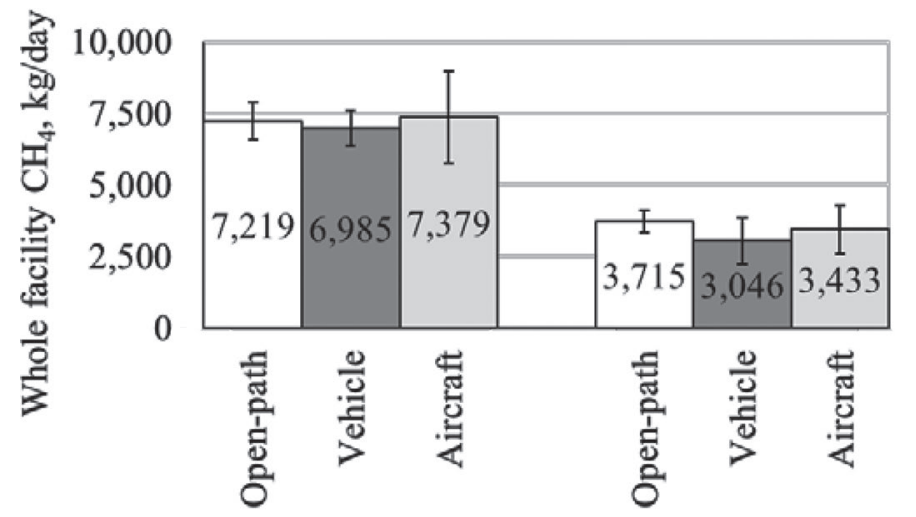

Dairy 1

Figure 3. Whole-facility methane $\left(\mathrm{CH}_{4}\right)$ emissions on dairy 1 and 2 during summer measurement periods in 2016. Emissions were estimated by open-path, vehicle, and aircraft. Error bars represent the $95 \%$ CI.

ter the morning and afternoon feeding (Supplemental Figure S5; https://doi.org/10.3168/jds.2017-13881). These peaks were in accordance with previous studies, which found that enteric $\mathrm{CH}_{4}$ emissions increased after feeding and were lower at night (Gao et al., 2011; Hegarty, 2013; Hammond et al., 2016). Consequently, the vehicle and aircraft techniques were expected to overestimate daily whole-facility $\mathrm{CH}_{4}$ emissions because both measured emissions primarily during the day and not during the night. In addition, vehicle and aircraft might have captured $\mathrm{CH}_{4}$ emissions from manure stockpiles (of VS recovered from the separator or lagoon evacuation) that were not captured by the open-path measurements. However, emissions from manure stockpiles were likely very low, as Ding et al. (2016) estimated that only $23.3 \pm 14.8 \mathrm{~g}$ of $\mathrm{CH}_{4} /$ head per day (mean $\pm \mathrm{SD}$ ) were emitted from manure stockpiles on a dry lot dairy in China. Nevertheless, no difference was detected $(P>0.05)$ in the whole-facility emissions, perhaps because the variability associated with the dif-

ferent measurement techniques was greater than the diurnal variability in $\mathrm{CH}_{4}$ emissions of the farms.

As we found no difference in whole-facility $\mathrm{CH}_{4}$ emissions among the measurement techniques, it can be assumed that the open-path estimates captured all significant on-farm $\mathrm{CH}_{4}$ sources on both dairies. Figure 4 shows the contribution of the different on-farm $\mathrm{CH}_{4}$ sources on dairy 1.

For animal housing, vehicle estimates were numerically greater than open-path estimates (Table 4), which might have been the result of limited nighttime measurements by the vehicle when housing emissions were low. For manure storage, vehicle estimates were within $5 \%$ of open-path estimates. Manure storage estimates were similar between the 2 techniques, possibly due to the lack of a diurnal trend in manure emissions (Supplemental Figures S5 and S6; https://doi.org/10.3168/ jds.2017-13881).

\section{Open-Path $\mathrm{CH}_{4}$ Estimates Broadly Tracked Monthly US EPA Estimates}

Open-path estimates for the 2 measurement periods (summer 2016 and winter 2017) were used to assess US EPA $\mathrm{CH}_{4}$ emission predictions from animal housing and liquid manure storage. As the main objective was to evaluate US EPA prediction equations for enteric and manure $\mathrm{CH}_{4}$ emissions, enteric and manure $\mathrm{CH}_{4}$ emissions were estimated from on-farm DMI rather than predicted DMI using US EPA (2017a) methodology. This approach allowed us to reduce variation in US EPA (2017a) $\mathrm{CH}_{4}$ predictions. This is especially important for the present study, as US EPA (2017a) emission factors are based on Holstein cattle and both of the studied dairies housed primarily Jersey cattle, which have a lower DMI $(\mathrm{kg} / \mathrm{d})$, and thus emission factor. For example, the US EPA (2017a) DMI estimate for a dairy cow (including lactating and dry cows) in California was 12.8 and $8.2 \%$ greater than the average

Table 3. Characteristics of methane emission measurements by open-path, vehicle, and aircraft methods in the present study

\begin{tabular}{|c|c|c|c|}
\hline \multirow[b]{2}{*}{ Characteristic } & \multicolumn{3}{|c|}{ Measurement technique } \\
\hline & Open-path & Vehicle & Aircraft \\
\hline Farm access & Yes & Yes & No \\
\hline Night measurements & Yes & Yes & No \\
\hline Continuous 24-h measurements & Yes & No & No \\
\hline Separation of emission sources & Yes & Yes $^{1}$ & No \\
\hline Whole-facility emissions & $\mathrm{Yes}^{2}$ & Yes & Yes \\
\hline Uncertainty in this study, ${ }^{3} \%$ & \pm 9 to 11 & \pm 9 to 27 & \pm 22 to 25 \\
\hline
\end{tabular}


DMI for dairy 1 and dairy 2 , respectively (21.2 vs. 18.8 and $19.6 \mathrm{~kg} /$ dairy cow per day).

Daily open-path $\mathrm{CH}_{4}$ estimates from animal housing during the summer and winter measurement periods
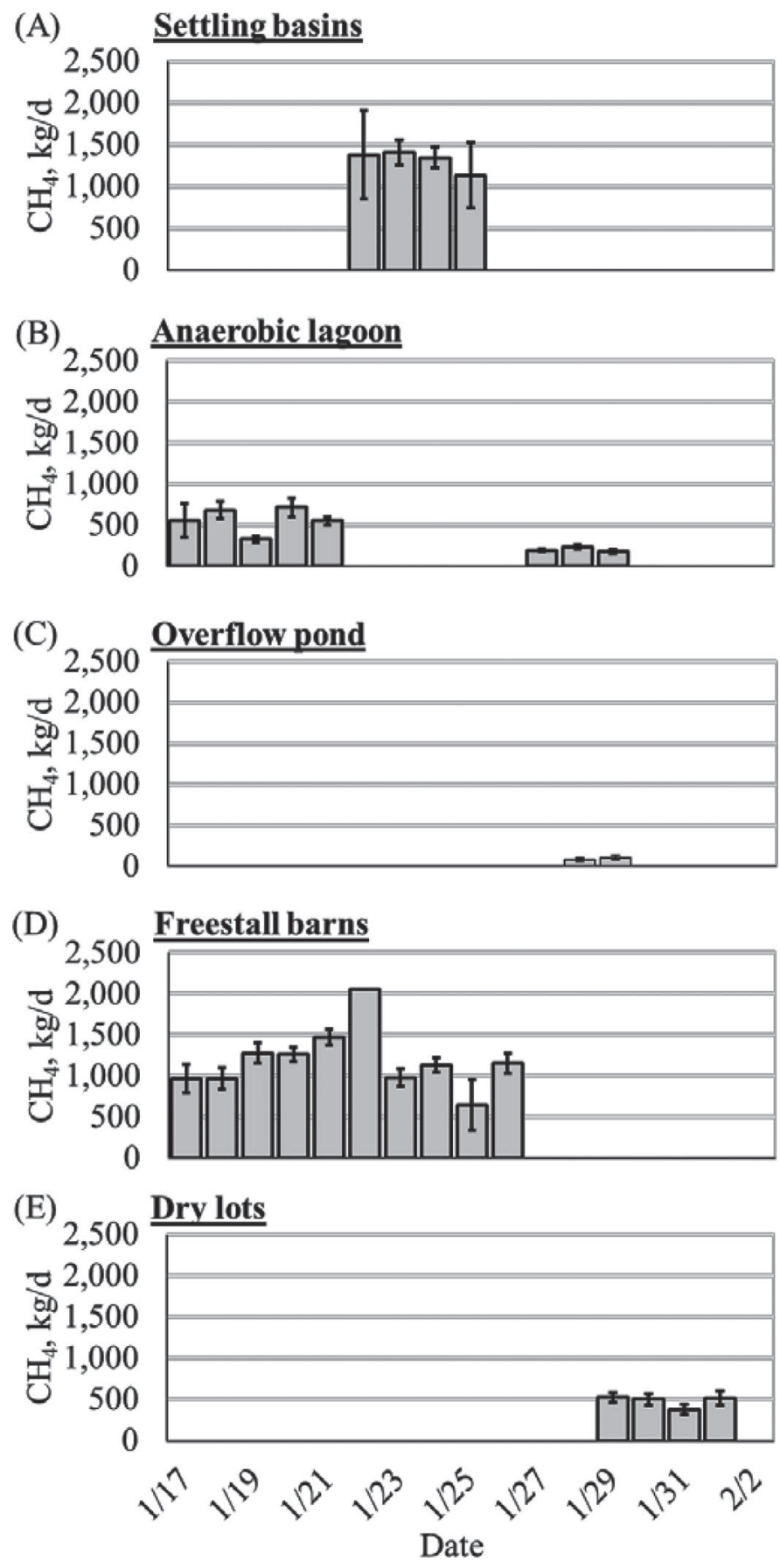

Figure 4. Daily methane $\left(\mathrm{CH}_{4}\right)$ emissions estimated by the openpath method from the different source areas on dairy 1 during the winter measurement period in 2017. The source areas presented in the figure are settling basins (A), anaerobic lagoon (B), overflow pond (C), freestall barns (housing - dairy cows) (C), and dry lots (housing-replacement heifers) (E). Error bars represent the 95\% CI. When no error bar is present, only 1 measurement was conducted. were similar within farms and to monthly US EPA estimates $(P>0.05$; data not shown $)$. Methane emissions from animal housing are primarily from enteric fermentation, with minor contributions from manure and bedding stored in the freestall barns and dry lots. As neither farm had major changes in diet composition, DMI or cattle numbers, which are drivers of enteric fermentation, enteric $\mathrm{CH}_{4}$ emissions were expected to be comparable between summer and winter measurement periods. Similarly, no difference in summer and winter $\mathrm{CH}_{4}$ emissions from the manure and bedding in the freestall barns and dry lots were expected because they are relatively low and other authors have not observed an effect of season on these emission sources. Rahman et al. (2013) found no difference in $\mathrm{CH}_{4}$ flux rates or fluxes of beef cattle pen surfaces among months over a 7-mo study in North Dakota. Borhan et al. (2011) found no effect of season on daily $\mathrm{CH}_{4}$ emissions for a freestall dairy barn (manure lane and bedding area) and its loafing pen.

Appuhamy et al. (2016) reported that the IPCC (2006b) Tier 2 model, which the US EPA (2017a) methodology is based on, was associated with a notable mean bias for over-predicting enteric $\mathrm{CH}_{4}$ emissions from lactating cows and thus was not ranked in the top 10 models for predicting enteric $\mathrm{CH}_{4}$ emissions. However, the US EPA (2017a) methodology predicted $\mathrm{CH}_{4}$ from animal housing (enteric $\mathrm{CH}_{4}$ emissions) similar to open-path measurements in our study. Thus, the findings of the present study indicate that the US EPA methodology, which is based on IPCC (2006b) guidelines, can be used to estimate $\mathrm{CH}_{4}$ emissions from animal housing if DMI data are available. The correlation between DMI and enteric $\mathrm{CH}_{4}$ emissions has been well documented in the literature (Hristov et al., 2013; Moraes et al., 2014; Niu et al., 2018). Although these findings should be confirmed by further studies, it appears that $\mathrm{CH}_{4}$ emissions from liquid manure storage could be estimated by subtracting housing $\mathrm{CH}_{4}$ emissions, predicted from DMI and the US EPA (2017a) model, from whole-facility $\mathrm{CH}_{4}$ emissions. This would allow estimation of manure $\mathrm{CH}_{4}$ emissions in cases where measurement techniques cannot distinguish between $\mathrm{CH}_{4}$ emissions from housing and liquid manure storage because of farm layout or the technique itself.

Open-path $\mathrm{CH}_{4}$ estimates from liquid manure storage (sum of $\mathrm{CH}_{4}$ emissions of all liquid manure storage facilities on each farm) broadly tracked both monthly US EPA (based on VS flow assumptions from US EPA, (2017a) and adjusted monthly US EPA estimates [based on VS flows determined from on-farm practices; Tables 2 and 5; Supplemental File S4 (https://doi.org/ 10.3168/jds.2017-13881); Figure 5]. The monthly US EPA estimate was similar to the open-path estimates 
Table 4. Contributions of different source areas to whole-facility methane $\left(\mathrm{CH}_{4}\right)$ emissions on dairy 1 and dairy 2 estimated by open-path and vehicle measurements during the summer measurement period

\begin{tabular}{lcccc}
\hline & & \multicolumn{3}{c}{ Liquid manure storage, $\mathrm{kg} / \mathrm{d}$} \\
\cline { 3 - 5 } Item & Animal housing, $\mathrm{kg} / \mathrm{d}$ & Total & Lagoon & Settling basin \\
\hline Dairy 1 & & & \\
$\quad$ Open-path & $2,330 \pm 466$ & $5,732 \pm 466$ & $1,566 \pm 313$ & $4,166 \pm 833$ \\
$\quad$ Vehicle & $2,601 \pm 811$ & $5,994 \pm 579$ & $\mathrm{ND}^{1}$ & $\mathrm{ND}$ \\
Dairy 2 & $1,275 \pm 255$ & $2,550 \pm 510$ & $220 \pm 44$ & $2,219 \pm 444$ \\
Open-path & $1,636 \pm 513$ & $\mathrm{ND}$ & $\mathrm{ND}$ & $2,141 \pm 637$ \\
Vehicle & & & \\
\hline
\end{tabular}

${ }^{1}$ Not determined.

on both dairies during the summer measurement period $(P>0.05)$ but not during the winter measurement period $(P \leq 0.05)$. During the winter measurement period, the monthly US EPA estimate was 0.6 and 2.3 times that measured on dairy 1 and 2, respectively. The adjusted monthly US EPA estimates were also similar to the open-path $\mathrm{CH}_{4}$ estimates on both dairies during the summer measurement periods $(P>0.05)$. During the winter measurement periods, the adjusted monthly US EPA estimate was similar to open-path estimates on dairy $1(P>0.05)$ but was 2.6 times the open-path estimates on dairy $2(P \leq 0.05)$. Although the relative differences between the open-path measurement and the monthly and adjusted monthly US EPA estimates was large, the numerical difference was relatively small considering yearly emission estimates. It was expected that adjusted monthly US EPA estimates would be more similar to the open-path estimates, as they were based on VS flows that were calculated from on-farm practices, which were different from US EPA (2017a) assumptions (Table 2). Based on calculations of on-farm practices, we assumed that more VS were stored in the liquid manure systems than based on US EPA assumptions. On dairy 1, US EPA assumed that $66 \%$ of VS excreted on the farm were stored in the liquid manure system, whereas, based on calculations of on-farm practices, $91 \%$ of the total VS stored in the liquid manure system (Table 5). On dairy 2, the corresponding estimates were 44 and $49 \%$, respectively. The lower amount of VS stored in the liquid manure system (27\%) based on US EPA (2017a) assumptions compared with on-farm practices on dairy 1 indicates that future studies should be conducted to validate US EPA assumptions.

In contrast to the present study, other measurements of liquid manure storage (settling basin and anaerobic lagoon or manure tanks) in the western United States and Canada have indicated that US EPA predictions of annual manure $\mathrm{CH}_{4}$ emissions may be underestimating on-farm emissions by up to $60 \%$ (Baldé et al., 2016; Leytem et al., 2017). A review of field-based studies on greenhouse gas emissions from dairy manure management also suggested that current $\mathrm{CH}_{4}$ emission factors generally underestimate emissions from liquid manuremanagement systems (Owen and Silver, 2015).

The great variability between open-path $\mathrm{CH}_{4}$ emission estimates from liquid manure storage during the summer and winter measurement periods shows that short-term measurements of $\mathrm{CH}_{4}$ emissions from liquid manure systems cannot be used to evaluate annual US EPA estimates or other BU inventories. Thus, we concluded that only TD inventory estimates based on long-term measurements (Miller et al., 2013; Jeong et al., 2016) can be used to validate BU inventories, and

Table 5. Daily manure and bedding volatile solids (VS) flow alone and as percent of manure VS excreted on dairy 1 and dairy 2 as predicted by US Environmental Protection Agency (US EPA) methodology and on-farm practices ${ }^{1}$

\begin{tabular}{|c|c|c|c|c|c|c|c|c|}
\hline Item & \multicolumn{2}{|c|}{ US EPA, $\mathrm{kg} / \mathrm{d}$} & \multicolumn{2}{|c|}{$\begin{array}{c}\text { On-farm } \\
\text { practices, } \mathrm{kg} / \mathrm{d}\end{array}$} & \multicolumn{2}{|c|}{$\begin{array}{c}\text { US EPA, \% } \\
\text { daily manure } \\
\text { VS excreted }\end{array}$} & \multicolumn{2}{|c|}{$\begin{array}{c}\text { On-farm practices, } \\
\% \text { daily manure } \\
\text { VS excreted }\end{array}$} \\
\hline $\begin{array}{l}\text { Manure VS excreted by all cattle } \\
\text { Manure and bedding VS }\end{array}$ & 24,443 & 18,629 & 24,443 & 18,629 & 100 & 100 & 100 & 100 \\
\hline Captured by flush & 19,295 & 16,250 & 24,443 & 19,061 & 79 & 87 & 100 & 102 \\
\hline Removed by lagoon emptying & 3,095 & 1,543 & 0 & 0 & 13 & 8 & 0 & 0 \\
\hline Stored in liquid manure system & 16,200 & 8,207 & 22,321 & 9,079 & 66 & 44 & 91 & 49 \\
\hline
\end{tabular}

\footnotetext{
${ }^{1}$ Assumes the US EPA and on-farm manure management practices outlined in Table 2.
} 
(A)

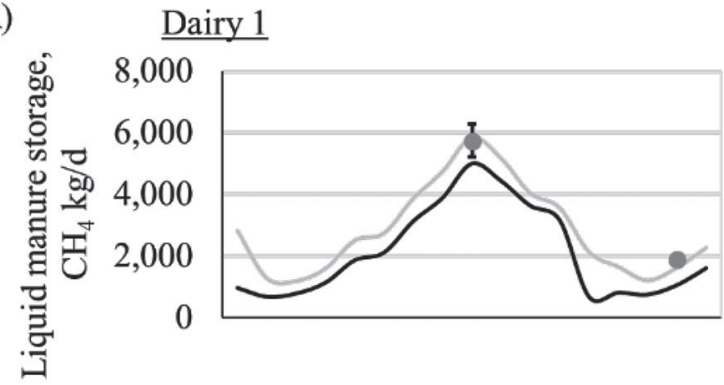

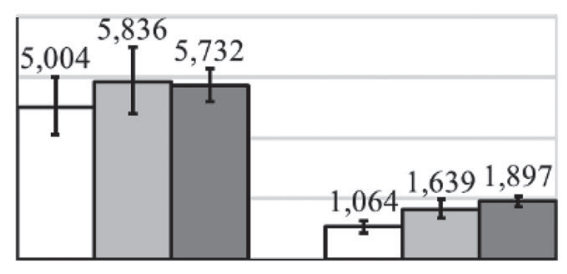

(B)

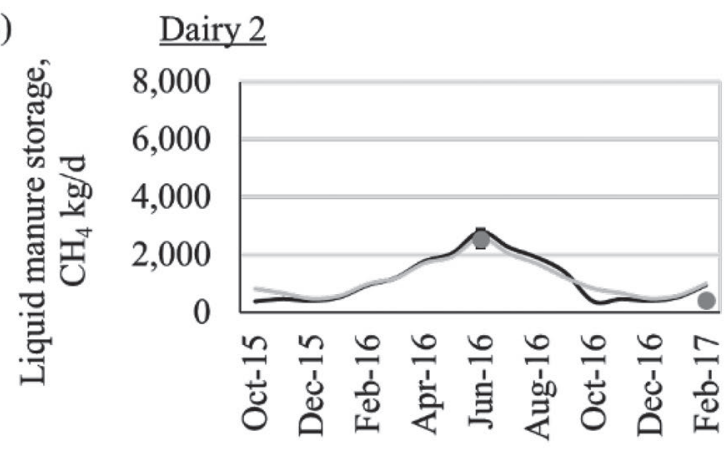

—US EPA — Adj. US EPA • Open-path

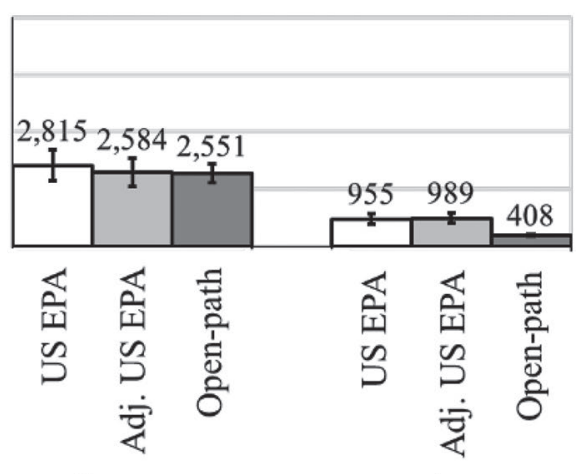

Summer

Winter

Figure 5. Monthly $\mathrm{CH}_{4}$ emission estimates from liquid manure storage based on US Environmental Protection Agency (EPA) and on-farm volatile solid (VS) flows (adj. US EPA) compared with the open-path estimates during the summer and winter measurement periods. Graphs (A) and (B) represent $\mathrm{CH}_{4}$ emissions from liquid manure storage on dairy 1 and 2, respectively. Error bars represent the $95 \%$ CI.

that TD inventories based on short-term measurements (Peischl et al., 2013; Wecht et al., 2014a,b; Trousdell et al., 2016; Cui et al., 2017) should not be used. However, publication of a spatially and temporally gridded US EPA emission inventory could allow for short-term comparisons of emission estimates.

Miller et al. (2013) and Jeong et al. (2016), using topdown approaches, both attributed greater annual $\mathrm{CH}_{4}$ emissions than the BU inventory estimates (US EPA and CARB) to ruminants and dairy livestock, respectively. Jeong et al. (2016) estimated that dairy livestock emitted more $\mathrm{CH}_{4}$ during winter than summer. This is the opposite of our findings, and the US EPA (2017a) inventory calculations, which predict an exponential increase of $\mathrm{CH}_{4}$ emissions from liquid manure storage with increasing temperatures during summer. Although we did not measure whole-facility $\mathrm{CH}_{4}$ emissions over a full year, the large on-farm variability in $\mathrm{CH}_{4}$ emissions from liquid manure storage indicated that the observed discrepancies between the TD and $\mathrm{BU}$ inventories were most likely caused by differences in $\mathrm{CH}_{4}$ emissions from liquid manure storage and not enteric fermentation, assuming that TD measurements correctly attribute emissions to dairy livestock.

\section{Open-Path Whole-Facility $\mathrm{CH}_{4}$ Estimates Varied Between the Dairies}

Whole-facility, animal housing, and liquid manure storage $\mathrm{CH}_{4}$ emissions for dairy 1 were greater than for dairy 2 (Table 6). Dairy 1 was expected to have greater $\mathrm{CH}_{4}$ emissions because it had 1.5 times more animal units (AU; Table 1), consuming 1.4 times more DM (76,448 vs. $53,906 \mathrm{~kg}$ of $\mathrm{DMI} / \mathrm{d})$ and producing 1.3 times more manure VS $(24,443$ vs. $18,629 \mathrm{~kg}$ of $\mathrm{VS} / \mathrm{d}$ ). As DMI is the driver for enteric $\mathrm{CH}_{4}$ emissions and manure VS are the substrate for manure $\mathrm{CH}_{4}$ emissions, we expected differences in daily enteric $\mathrm{CH}_{4}$ emissions similar to the difference in DMI, as well as a difference in daily manure $\mathrm{CH}_{4}$ emissions similar to the difference in manure VS production. On dairy 1, daily $\mathrm{CH}_{4}$ emissions from animal housing were 1.3 times greater than on dairy 2 , and thus similar to the difference in DMI (Table 6). However, liquid manure storage $\mathrm{CH}_{4}$ emissions on dairy 1 were, on average, 3.5 times greater than on dairy 2 , and thus much greater than the 1.3 times difference that we expected based on the difference in VS production. Data were normalized to account for the differences in AU, DMI, and VS excre- 
tion to further investigate variation in $\mathrm{CH}_{4}$ emissions between the farms.

Emissions from animal housing (g of $\mathrm{CH}_{4} / \mathrm{AU}$ ) were 1.2 times greater on dairy 2 than dairy 1 during the summer measurement period $(P \leq 0.05)$, but similar between both farms during the winter measurement period $(P>0.05)$. This difference between the farms might have resulted from the relatively greater DMI on dairy 2 compared with dairy 1 during the summer measurement period (21.3 vs. $20.1 \mathrm{~kg}$ of DMI/lactating cow per day) compared with the winter measurement period (20.3 vs. $19.9 \mathrm{~kg}$ of DMI/lactating cow per day). This hypothesis is supported by similar $\mathrm{CH}_{4}$ yields ( $\mathrm{g}$ of $\mathrm{CH}_{4} / \mathrm{kg}$ of DMI) from animal housing across the farms and seasons (Figure 6). On dairy 1 and $2, \mathrm{CH}_{4}$ yields from animal housing averaged $20.2 \mathrm{~g}$ of $\mathrm{CH}_{4} / \mathrm{kg}$ of DMI $(95 \% \mathrm{CI}=19.0-21.4)$ and $21.6 \mathrm{~g}$ of $\mathrm{CH}_{4} / \mathrm{kg}$ of DMI $(95 \%$ CI $=19.4-23.6)$, respectively.

Emissions from liquid manure storage ( $\mathrm{g}$ of $\mathrm{CH}_{4} /$ $\mathrm{AU})$ were 1.5 and 3.2 times greater on dairy 1 than on dairy 2 during the summer and winter measurement periods, respectively. Consequently, the whole-facility $\mathrm{CH}_{4}$ emissions per $\mathrm{AU}$ on dairy 1 was greater than on dairy 2 , likely driven by greater VS stored in liquid manure. Similar patterns were observed for $\mathrm{CH}_{4}$ emissions normalized by VS loading from liquid manure storage $\left[\mathrm{CH}_{4}(\mathrm{~g} / \mathrm{d}) / \mathrm{VS}(\mathrm{kg} / \mathrm{d})\right.$ produced by all cattle; Figure 6]. Methane emissions normalized by VS loading from liquid manure storage on dairy 1 were 1.7 and 3.5 times greater than on dairy 2 during the summer and winter measurement periods, respectively. Dairy 1 stored a relatively greater proportion of VS in liquid than dairy 2 because it did not have a manure separator and housed a greater proportion of dairy cows in freestall barns from which manure and bedding VS were collected by flushing. VanderZaag et al. (2018) found that a screw press separator that removed $78 \%$ of VS reduced the $\mathrm{CH}_{4}$ emission potential by $81 \%$ on a volume basis. In addition, differences in manure handling could have contributed to the reduced emissions on dairy 2 . The primary settling basin on dairy 2 was shallower (approximately 3 vs. $6 \mathrm{~m}$ on dairy 1) and therefore may have had a lower $\mathrm{CH}_{4}$-generation potential. According to IPCC (2006a), shallow anaerobic waste water lagoons ( $<2 \mathrm{~m}$ in depth) have a $\mathrm{CH}_{4}$ conversion factor between 0.0 and 0.3 , and deep anaerobic waste water lagoons ( $>2 \mathrm{~m}$ in depth) have a $\mathrm{CH}_{4}$ conversion factor between 0.8 and 1.0. In addition, the settling basins on dairy 2 were cleaned out more recently; thus, they had less inoculum than the settling basins on dairy 1 and may have had reduced $\mathrm{CH}_{4}$-generation potential (Vanderzaag et al., 2013). The possibility exists that different chemicals used in the wash water from the milking parlor could have an effect on $\mathrm{CH}_{4}$ emissions;

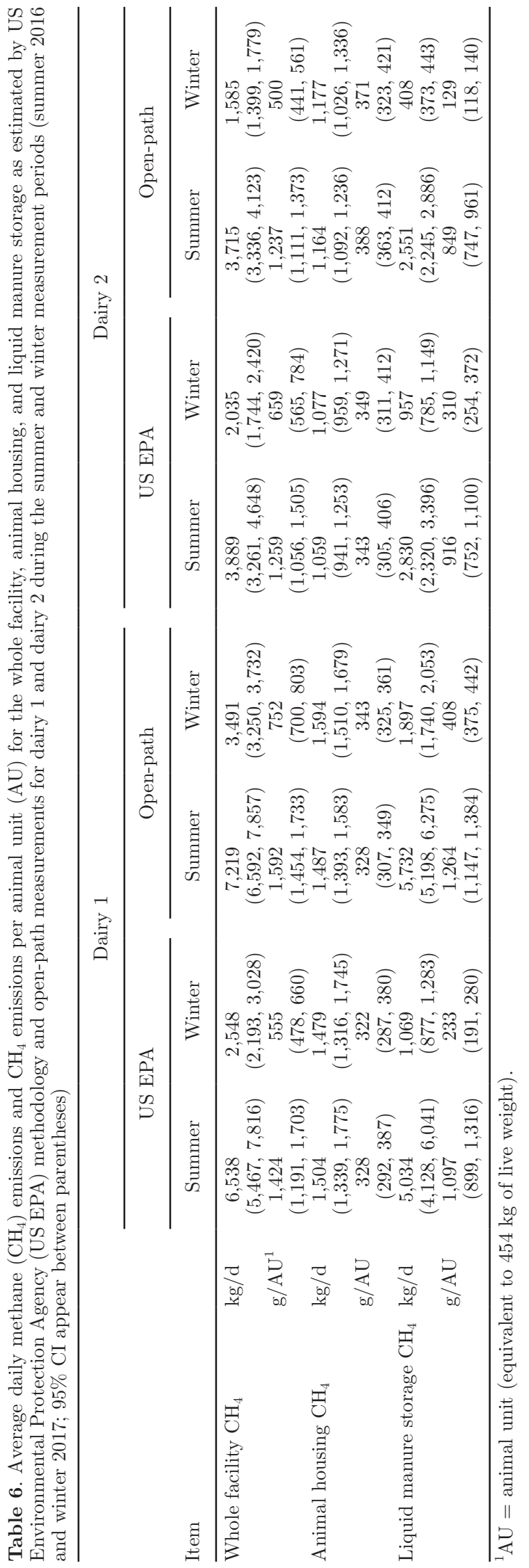


(A)

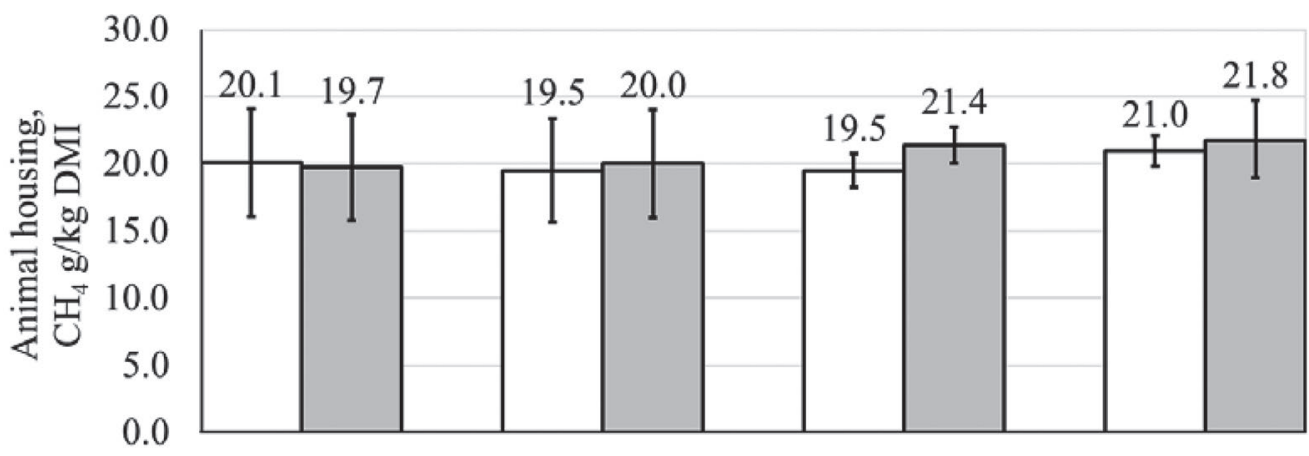

(B)

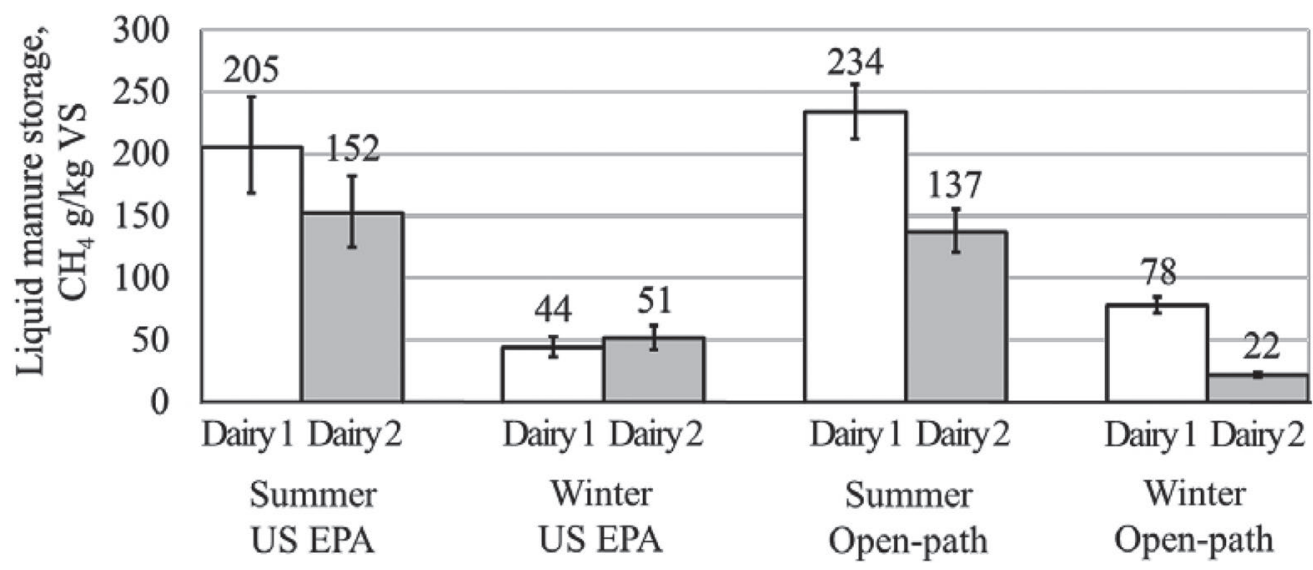

Figure 6. Summer and winter methane $\left(\mathrm{CH}_{4}\right)$ emissions predicted by US Environmental Protection Agency (US EPA) methodology and estimated by open-path for dairy 1 and dairy 2 during the summer and winter measurement periods. Figure $(\mathrm{A})$ shows animal housing $\mathrm{CH}_{4}$ emissions over DMI and (B) shows liquid manure storage $\mathrm{CH}_{4}$ emissions normalized by volatile solids (VS) loading on each dairy. Error bars represent the $95 \%$ CI.

however, we were unable to get detailed information on all chemicals used in the milking parlors.

The ratio of enteric to manure $\mathrm{CH}_{4}$ emissions on dairy 1 were 21:79 and 46:54 during summer and winter, respectively; the corresponding values on dairy 2 were 31:69 and 74:26. These results suggest that manure management on dairy 1 might have contributed more than the $55 \%$ of whole-facility $\mathrm{CH}_{4}$ emissions estimated by the current inventory (CARB, 2017).

\section{Methane Emissions Varied Between and Within Source Area}

Different $\mathrm{CH}_{4}$ emissions were observed between and within on-farm sources (Figures 4 and 7 ). On dairy 1 , open-path estimated greater $\mathrm{CH}_{4}$ emissions for the freestall barns to the west $\left[1,148 \mathrm{~kg}\right.$ of $\mathrm{CH}_{4} / \mathrm{d}(95 \%$ CI $=1,106-1,192)]$ than for the dry lots to the east [446 kg of $\left.\mathrm{CH}_{4} / \mathrm{d}(95 \% \mathrm{CI}=404-487)\right]$. The US EPA (2017a) methodology estimated $\mathrm{CH}_{4}$ emissions similar to the open-path estimates for the freestall barns $[1,296 \mathrm{~kg}$ of $\left.\mathrm{CH}_{4} / \mathrm{d}(95 \% \mathrm{CI}=1,129-1,497)\right]$, but less $\mathrm{CH}_{4}$ emissions for the dry lots $\left[188 \mathrm{~kg}\right.$ of $\left.\mathrm{CH}_{4} / \mathrm{d}(95 \% \mathrm{CI}=167-222)\right]$.
A prediction equation for enteric $\mathrm{CH}_{4}$ emissions from heifers, developed by Jiao et al. (2013), estimated similar $\mathrm{CH}_{4}$ emissions to US EPA $\left[283 \mathrm{~kg}\right.$ of $\mathrm{CH}_{4} / \mathrm{d}(95 \% \mathrm{CI}$ $=201-366)]$ for the dry lots to the east. It is possible that manure $\mathrm{CH}_{4}$ emissions from dry lots were greater because the lots were muddy with patches of standing water. However, this hypothesis cannot be validated because dry lot emissions were not measured during the summer measurement period. In addition, it is possible that the prediction equation for heifers underestimated their emissions.

The various parts of the liquid manure storage systems on dairy 1 (2 settling basins, anaerobic lagoon, and overflow pond) and dairy 2 (1 settling basin, anaerobic lagoon, and flush pond) contributed different amounts of $\mathrm{CH}_{4}$ to the overall liquid manure storage emissions during the summer and winter measurement periods (Figure 7 ). On dairy 1, the settling basins were the largest source of $\mathrm{CH}_{4}$ emissions from liquid manure storage during the summer and winter measurement periods despite significantly lower total $\mathrm{CH}_{4}$ emissions from liquid manure storage during winter. On dairy 2, the settling basin was the largest source of $\mathrm{CH}_{4}$ emis- 
(A)

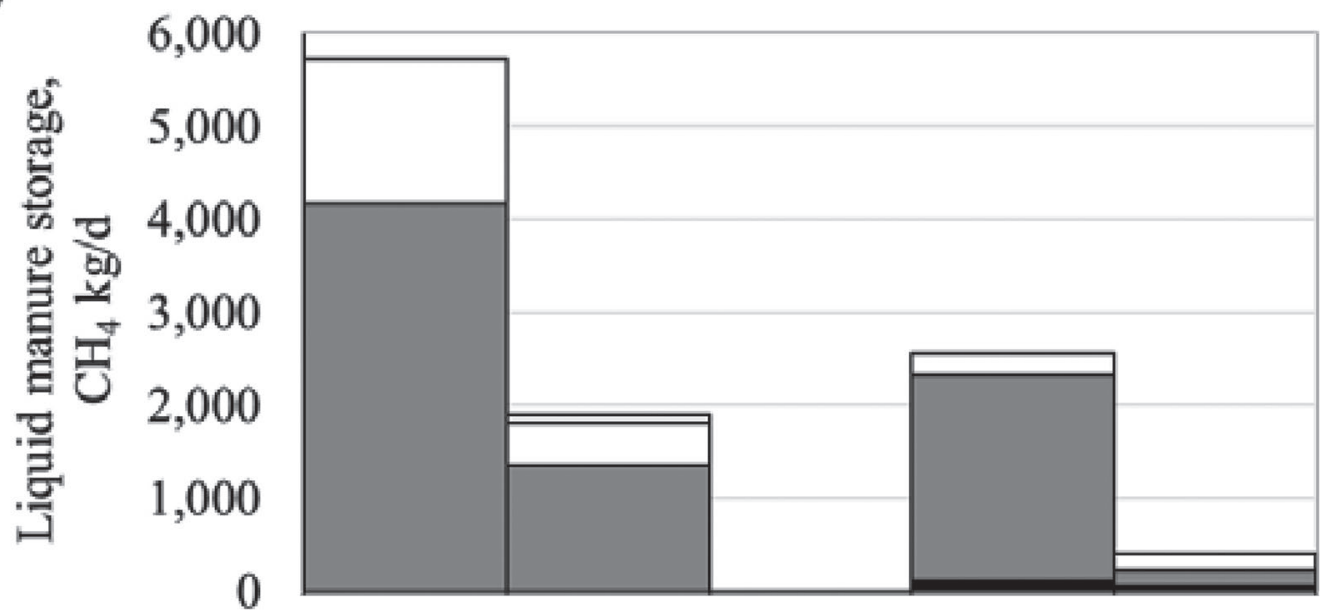

(B)

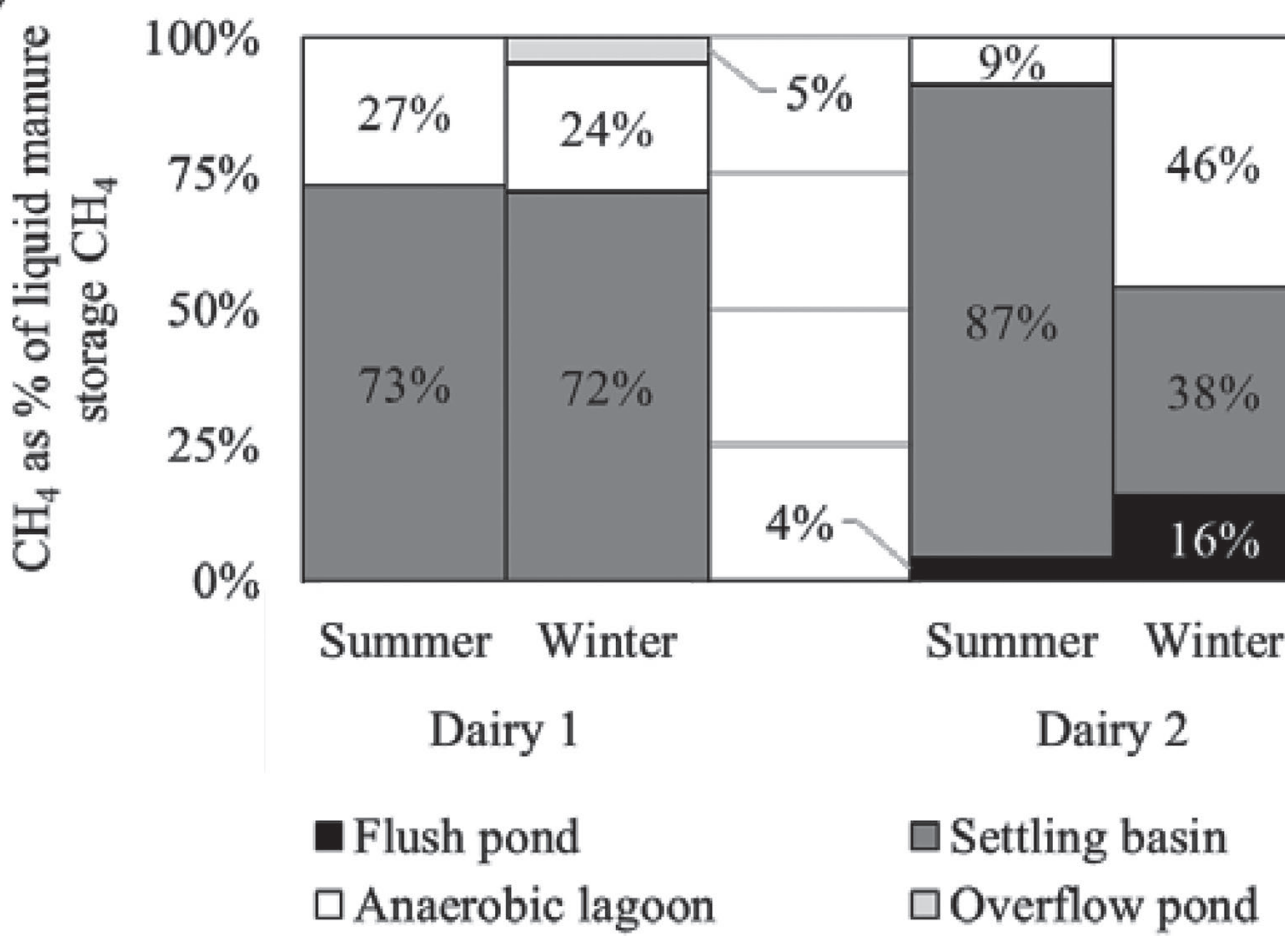

Figure 7. Methane $\left(\mathrm{CH}_{4}\right)$ emissions from different liquid manure storage components (settling basin, anaerobic lagoon, overflow pond, and flush pond). Emissions are shown per day (A) and as percentage of total liquid manure emissions (B).

sions from liquid manure storage during the summer measurement period, whereas the anaerobic lagoon was the largest source of $\mathrm{CH}_{4}$ emissions during the winter measurement period. Leytem et al. (2017) and Borhan et al. (2011) observed that settling basins generated more $\mathrm{CH}_{4}$ than anaerobic lagoons during the summer but not the winter measurement period on 2 different dairies. Leytem et al. (2017) suggested that $\mathrm{CH}_{4}$ emissions from settling basins may be more affected by ambient temperature than $\mathrm{CH}_{4}$ emissions from anaerobic lagoons because of their relatively smaller storage volume. It is possible that a different emission pattern was observed on dairy 1 because 2 sequential settling basins were used, whereas dairy 2 and the dairies studied by Leytem et al. (2017) and Borhan et al. (2011) used only 1 settling basin. In addition, each of the settling basins on dairy 1 were relatively large and about twice the size of the settling basin on dairy 2 . Thus, the settling basins on dairy 1 may have functioned similar to an anaerobic lagoon.

Anaerobic lagoon emissions were more than 2 times greater during the first week compared with the second 
week of the winter measurements on dairy 1 (596 vs. $207 \mathrm{~kg}$ of $\mathrm{CH}_{4} / \mathrm{d}$; Figure 4B). Storms occurred each day during the first week of measurements from January 18 to 22 and may have caused agitation of the anaerobic lagoon, resulting in greater $\mathrm{CH}_{4}$ emissions. Baldé et al. (2016) found that agitation, such as rain events, led to increased emissions in a concrete storage tank; however, those authors noted that the increased emissions may just be over the short-term and not substantially increase overall emission rates. Baldé et al. (2016) estimated that $\mathrm{CH}_{4}$ emission surges caused by agitation events increased the daily $\mathrm{CH}_{4}$ emission rate by 3 to $8 \%$. VanderZaag et al. (2014) noted that high emissions during agitation were offset by very low emissions after agitation, suggesting that the overall effect of high fluxes on total emissions is minimal. Although $\mathrm{CH}_{4}$ surges just slightly increased daily $\mathrm{CH}_{4}$ emissions when long-term measurements were conducted, these surges could cause an overestimation of $\mathrm{CH}_{4}$ emissions during short-term measurements.

In summary, the variation between and within $\mathrm{CH}_{4}$ emission sources indicate that it is important to take representative measurements of all housing and liquid manure storage facilities on a dairy. Furthermore, all liquid manure storage areas need to be assessed repeatedly to make sure that representative $\mathrm{CH}_{4}$ emissions are measured and the possibility of overestimating or underestimating emissions is reduced due to $\mathrm{CH}_{4}$ surges or decreased emissions after $\mathrm{CH}_{4}$ surges.

\section{CONCLUSIONS}

Although the number of measurements was limited in this study, we were able to compare different techniques for measuring whole-facility $\mathrm{CH}_{4}$ emissions and found similar results among techniques. The open-path and vehicle techniques were able to distinguish between daily $\mathrm{CH}_{4}$ emissions from animal housing (primarily enteric fermentation) and liquid manure storage, the 2 main $\mathrm{CH}_{4}$ sources on the studied farms. The openpath results for $\mathrm{CH}_{4}$ emissions from animal housing were similar to monthly US EPA estimates, which were predicted using farm DMI and US EPA methodology. This indicates that US EPA estimates for $\mathrm{CH}_{4}$ produced by enteric fermentation may be used to predict $\mathrm{CH}_{4}$ emissions from manure storage by subtracting US EPA enteric $\mathrm{CH}_{4}$ estimates from whole-facility $\mathrm{CH}_{4}$ emissions (housing and liquid manure storage) when separate emissions estimates are not available. Openpath estimates for $\mathrm{CH}_{4}$ emissions from liquid manure storage broadly tracked monthly US EPA estimates. The proportion of $\mathrm{CH}_{4}$ contributed by the different liquid manure storage facilities changed over time. On 1 dairy, US EPA assumptions estimated that $27 \%$ more
VS were stored in the liquid manure system than based on calculations of on-farm management practices. In the future, US EPA VS flow assumptions should be validated and possible improvements could be made by including different manure management systems, such as anaerobic lagoons for replacement heifers and dry lots, for dairy cows. Furthermore, $\mathrm{CH}_{4}$ emissions from liquid manure should be measured on a monthly basis or more frequently throughout the year to validate the US EPA $\mathrm{CH}_{4}$ prediction for liquid manure management, as other research has found that the US EPA methodology may over- or underestimate monthly $\mathrm{CH}_{4}$ emissions. Substantial differences in $\mathrm{CH}_{4}$ emissions from liquid manure storage ( $\mathrm{g}$ of $\mathrm{CH}_{4} / \mathrm{kg}$ of $\mathrm{VS}$ ) between the 2 dairies indicated that $\mathrm{CH}_{4}$ emissions from California dairy farms could be significantly reduced by changes in manure management practices. However, future research is needed to evaluate the potential tradeoffs between manure stored in dry and liquid systems.

\section{ACKNOWLEDGMENTS}

C. Arndt's postdoctoral fellowship at Environmental Defense Fund and part of A. N. Hristov's time were funded by a gift from Sue and Steve Mandel and the Kravis Scientific Research Fund (New York, NY). The measurements were funded by a gift from Sue and Steve Mandel and the Robertson Foundation (New York, NY). I. Faloona was supported by the California Agricultural Experiment Station, Hatch project CAD-LAW-2229-H. We thank E. Kebreab, M. Hess, and their laboratories at University of California, Davis, for assistance with sample preparation and $\mathrm{CH}_{4}$ analysis, respectively.

\section{REFERENCES}

Allen, M. S. 2000. Effects of diet on short-term regulation of feed intake by lactating dairy cattle. J. Dairy Sci. 83:1598-1624. https:// doi.org/10.3168/jds.S0022-0302(00)75030-2 (Review).

Appuhamy, J. A. D. R. N., J. France, and E. Kebreab. 2016. Models for predicting enteric methane emissions from dairy cows in North America, Europe, and Australia and New Zealand. Glob. Chang. Biol. 22:3039-3056. https://doi.org/10.1111/gcb.13339.

Baldé, H., A. C. VanderZaag, S. Burtt, L. Evans, C. Wagner-Riddle, R. L. Desjardins, and J. D. MacDonald. 2016. Measured versus modeled methane emissions from separated liquid dairy manure show large model underestimates. Agric. Ecosyst. Environ. 230:261-270. https://doi.org/10.1016/j.agee.2016.06.016.

Bergamaschi, P., M. Corazza, U. Karstens, M. Athanassiadou, R. L. Thompson, I. Pison, A. J. Manning, P. Bousquet, A. Segers, A. T. Vermeulen, G. Janssens-Maenhout, M. Schmidt, M. Ramonet, F. Meinhardt, T. Aalto, L. Haszpra, J. Moncrieff, M. E. Popa, D. Lowry, M. Steinbacher, A. Jordan, S. O'Doherty, S. Piacentino, and E. Dlugokencky. 2015. Top-down estimates of European $\mathrm{CH}_{4}$ and $\mathrm{N}_{2} \mathrm{O}$ emissions based on four different inverse models. Atmos. Chem. Phys. 15:715-736. https://doi.org/10.5194/acp-15 $-715-2015$. 
Borhan, M. S., S. Capareda, S. Mukhtar, W. B. Faulkner, R. McGee, and C. B. Parnell. 2011. Determining seasonal greenhouse gas emissions from ground-level area sources in a dairy operation in central Texas. J. Air Waste Manag. Assoc. 61:786-795. https:// doi.org/10.3155/1047-3289.61.7.786.

CARB. 2017. Documentation of California's 2000-2015 GHG inventory-Index. California Air Resource Board, Sacramento, CA. Accessed Mar. 17, 2018. https://www.arb.ca.gov/cc/inventory/doc/ doc_index.php.

CDFA. 2017. California cost of milk production Annual 2016. California Department of Food and Agricultura, Sacramento, CA Accessed Mar. 17, 2018. https://www.cdfa.ca.gov/dairy/pdf/ Annual/2016/COP_Annual2016Data.pdf.

Conley, S., I. Faloona, S. Mehrotra, M. Suard, D. H. Lenschow, C. Sweeney, S. Herndon, S. Schwietzke, G. Pétron, J. Pifer, E. A Kort, and R. Schnell. 2017. Application of Gauss's theorem to quantify localized surface emissions from airborne measurements of wind and trace gases. Atmos. Meas. Tech. 10:3345-3358. https: //doi.org/10.5194/amt-10-3345-2017.

Cui, Y. Y., J. Brioude, W. M. Angevine, J. Peischl, S. A. McKeen, S.W. Kim, J. A. Neuman, D. K. Henze, N. Bousserez, M. L. Fischer, S. Jeong, H. A. Michelsen, R. P. Bambha, Z. Liu, G. W. Santoni, B. C. Daube, E. A. Kort, G. J. Frost, T. B. Ryerson, S. C. Wofsy, and M. Trainer. 2017. Top-down estimate of methane emissions in California using a mesoscale inverse modeling technique: The San Joaquin Valley. J. Geophys. Res. 122:3686-3699. https://doi.org/ 10.1002/2016JD026398.

Deshpande, B., L. Hunsaker, M. Vayssières, K. Lutter, K. Eslinger, K. Scott, and A. Huang. 2014. California's 2000-2012 Greenhouse gas emissions inventory-Technical support document. California Air Resource Board, Sacramento.

DeVries, T. J., and M. A. G. von Keyserlingk. 2009. Short communication: Feeding method affects the feeding behavior of growing dairy heifers. J. Dairy Sci. 92:1161-1168. https://doi.org/10.3168/ jds.2008-1314.

Ding, L., Q. Lu, L. Xie, J. Liu, W. Cao, Z. Shi, B. Li, C. Wang, G. Zhang, and S. Ren. 2016. Greenhouse gas emissions from dairy open lot and stockpile in northern China: A case study. J. Air Waste Manag. Assoc. 66:267-279. https://doi.org/10.1080/ 10962247.2015.1124058.

Eaton, A. D., L. S. Clesceri, E. W. Rice, and A. E. Greenberg. 2005. Standard Methods for the Examination of Water and Wastewater. 21st ed. American Public Health Association, American Water Works Association, Water Environment Federation. Port City Press, Baltimore, MD.

Efron, B., and R. J. Tibshirani. 1993. An Introduction to the Bootstrap: Monographs on Statistics and Applied Probability. Vol. 57. Chapman Hall-CRC, New York, NY

Flesch, T. K., J. D. Wilson, and L. A. Harper. 2005. Deducing groundto-air emissions from observed trace gas concentrations: A field trial with wind disturbance. J. Appl. Meteorol. 44:475-484. https: //doi.org/10.1175/jam2214.1.

Flesch, T. K., J. D. Wilson, L. A. Harper, B. P. Crenna, and R. R. Sharpe. 2004. Deducing ground-to-air emissions from observed trace gas concentrations: A field trial. J. Appl. Meteorol. 43:487502. https://doi.org/10.1175/1520-0450(2004)043<0487:dgefot $>2$. $0 . \operatorname{co} ; 2$.

Gao, Z., H. Yuan, W. Ma, J. Li, X. Liu, and R. L. Desjardins. 2011. Diurnal and seasonal patterns of methane emissions from a dairy operation in north china plain. Adv. Meteorol. 2011:1902347. https://doi.org/10.1155/2011/190234.

Gomez, A., and N. B. Cook. 2010. Time budgets of lactating dairy cattle in commercial freestall herds. J. Dairy Sci. 93:5772-5781. https://doi.org/10.3168/jds.2010-3436.

Grant, R. 2009. Stocking density and time budgets. Pages 7-17 in 2009 Proceedings of Western Dairy Management Conference, Reno, NV.

Greter, A. M., T. J. DeVries, and M. A. G. von Keyserlingk. 2008. Nutrient intake and feeding behavior of growing dairy heifers: Effects of dietary dilution. J. Dairy Sci. 91:2786-2795. https://doi.org/10 $.3168 /$ jds.2008-1052.
Greter, A. M., M. A. G. von Keyserlingk, and T. J. DeVries. 2012 Ration composition affects short-term diurnal feeding patterns of dairy heifers. Appl. Anim. Behav. Sci. 140:16-24. https://doi.org/ 10.1016/j.applanim.2012.04.013.

Griffiths, P. R., L. Shao, and A. B. Leytem. 2009. Completely automated open-path FT-IR spectrometry. Anal. Bioanal. Chem. 393:45-50. https://doi.org/10.1007/s00216-008-2429-6.

Hammond, K. J., L. A. Crompton, A. Bannink, J. Dijkstra, D. R Yáñez-Ruiz, P. O'Kiely, E. Kebreab, M. A. Eugenè, Z. Yu, K. J. Shingfield, A. Schwarm, A. N. Hristov, and C. K. Reynolds. 2016. Review of current in vivo measurement techniques for quantifying enteric methane emission from ruminants. Anim. Feed Sci. Technol. 219:13-30. https://doi.org/10.1016/j.anifeedsci.2016.05.018.

Hegarty, R. S. 2013. Applicability of short-term emission measurements for on-farm quantification of enteric methane. Animal 7:401-408. https://doi.org/10.1017/S1751731113000839.

Herndon, S. C., J. T. Jayne, M. S. Zahniser, D. R. Worsnop, B. Knighton, E. Alwine, B. K. Lamb, M. Zavala, D. D. Nelson, J. B. McManus, J. H. Shorter, M. R. Canagaratna, T. B. Onasch, and C. E. Kolb. 2005. Characterization of urban pollutant emission fluxes and ambient concentration distributions using a mobile laboratory with rapid response instrumentation. Faraday Discuss. 130:327339. https://doi.org/10.1039/b500411j.

Hristov, A., J. Oh, C. Lee, R. Meinen, F. Montes, T. Ott, J. Firkins, A. Rotz, C. Dell, and A. Adesogan. 2013. Mitigation of Greenhouse Gas Emissions in Livestock Production: A Review of Technical Options for Non- $\mathrm{CO}_{2}$ Emissions. Food and Agriculture Organization of the United Nations, Rome, Italy.

Hristov, A. N., M. Harper, R. Meinen, R. Day, J. Lopes, T. Ott, A. Venkatesh, and C. A. Randles. 2017. Discrepancies and uncertainties in bottom-up gridded inventories of livestock methane emissions for the contiguous united states. Environ. Sci. Technol. 51:13668-13677. https://doi.org/10.1021/acs.est.7b03332.

IPCC. 2006a. Wastewater treatment and discharge. Pages 6.1-6.28 in IPCC Guidelines for National Greenhouse Gas Inventories Volume 4: Agriculture, Forestry and Other Land Use. IGES, Cambridge, United Kingdom.

IPCC. 2006b. Emissions from livestock and manure management. Pages 10.1-10.87 in IPCC Guidelines for National Greenhouse Gas Inventories Volume 4: Agriculture, Forestry and Other Land Use. IGES Cambridge, United Kingdom.

IPCC. 2013. Climate Change 2013: The Physical Science Basis. Contribution of Working Group I to the Fifth Assessment Report of the Intergovernmental Panel on Climate Change. Cambridge University Press, Cambridge, United Kingdom. https://doi.org/10 $.1017 /$ CBO9781107415324.

Jeong, S., S. Newman, J. Zhang, A. E. Andrews, L. Bianco, J. Bagley, X. Cui, H. Graven, J. Kim, P. Salameh, B. W. LaFranchi, C Priest, M. Campos-Pineda, E. Novakovskaia, C. D. Sloop, H. A. Michelsen, R. P. Bambha, R. F. Weiss, R. Keeling, and M. L. Fischer. 2016. Estimating methane emissions in California's urban and rural regions using multitower observations. J. Geophys. Res. 121:13031-13049. https://doi.org/10.1002/2016JD025404.

Jiao, H. P.. T. Yan, D. A. McDowell, A. F. Carson, C. P. Ferris, D. L. Easson, and D. Wills. 2013. Enteric methane emissions and efficiency of use of energy in Holstein heifers and steers at age of six months. J. Anim. Sci. 91:356-362. https://doi.org/10.2527/jas .2012-5259.

Lamb, B. K., J. B. McManus, J. H. Shorter, C. E. Kolb, B. Mosher, R. C. Harriss, E. Allwine, D. Blaha, T. Howard, A. Guenther, R. A. Lott, R. Siverson, H. Westburg, and P. Zimmerman. 1995. Development of atmospheric tracer methods to measure methane emissions from natural gas facilities and urban areas. Environ. Sci. Technol. 29:1468-1479. https://doi.org/10.1021/es00006a007.

Legrand, A. L., M. A. G. von Keyserlingk, and D. M. Weary. 2009 Preference and usage of pasture versus free-stall housing by lactating dairy cattle. J. Dairy Sci. 92:3651-3658. https://doi.org/10 $.3168 /$ jds.2008-1733.

Leytem, A. B., D. L. Bjorneberg, A. C. Koehn, L. E. Moraes, E. Kebreab, and R. S. Dungan. 2017. Methane emissions from dairy 
lagoons in the western United States. J. Dairy Sci. 100:6785-6803. https://doi.org/10.3168/jds.2017-12777.

Maynard, L. A., J. K. Loosli, H. F. Hintz, and R. G. Warner. 1979. Animal Nutition. 7th. McGraw Hill Inc., New York, NY.

Miller, S. M., S. C. Wofsy, A. M. Michalak, E. A. Kort, A. E. Andrews, S. C. Biraud, E. J. Dlugokencky, J. Eluszkiewicz, M. L. Fischer, G. Janssens-Maenhout, B. R. Miller, J. B. Miller, S. A. Montzka, T. Nehrkorn, and C. Sweeney. 2013. Anthropogenic emissions of methane in the United States. Proc. Natl. Acad. Sci. USA 110:20018-20022. https://doi.org/10.1073/pnas.1314392110.

Mønster, J. G. J. Samuelsson, P. Kjeldsen, C. W. Rella, and C. Scheutz. 2014. Quantifying methane emission from fugitive sources by combining tracer release and downwind measurements- $\mathrm{A}$ sensitivity analysis based on multiple field surveys. Waste Manag. 34:1416-1428. https://doi.org/10.1016/j.wasman.2014.03.025.

Moraes, L. E., A. B. Strathe, J. G. Fadel, D. P. Casper, and E. Kebreab. 2014. Prediction of enteric methane emissions from cattle. Glob. Chang. Biol. 20:2140-2148. https://doi.org/10.1111/gcb .12471.

Niu, M., E. Kebreab, A. N. Hristov, J. Oh, C. Arndt, A. Bannink, A. R. Bayat, A. F. Brito, T. Boland, D. Casper, L. A. Crompton, J. Dijkstra, M. A. Eugène, P. C. Garnsworthy, M. N. Haque, A. L. F. Hellwing, P. Huhtanen, M. Kreuzer, B. Kuhla, P. Lund, J. Madsen, C. Martin, S. C. Mcclelland, M. Mcgee, P. J. Moate, S. Muetzel, C. Muñoz, P. O'Kiely, N. Peiren, C. K. Reynolds, A. Schwarm, K. J. Shingfield, T. M. Storlien, M. R. Weisbjerg, D. R. Yáñez-Ruiz, and Z. Yu. 2018. Prediction of enteric methane production, yield, and intensity in dairy cattle using an intercontinental database. Glob. Chang. Biol. 24:3368-3389. https://doi .org/10.1111/gcb.14094.

NRC. 2001. Nutrient Requirement of Dairy Cattle. 7th rev. ed. Natl. Acad. Press, Washington, DC.

Owen, J. J., and W. L. Silver. 2015. Greenhouse gas emissions from dairy manure management: a review of field-based studies. Glob. Chang. Biol. 21:550-565. https://doi.org/10.1111/gcb.12687.

Peischl, J., T. B. Ryerson, J. Brioude, K. C. Aikin, A. E. Andrews, E. Atlas, D. Blake, B. C. Daube, J. A. de Gouw, E. Dlugokencky, G. J. Frost, D. R. Gentner, J. B. Gilman, A. H. Goldstein, R. A. Harley, J. S. Holloway, J. Kofler, W. C. Kuster, P. M. Lang, P. C. Novelli, G. W. Santoni, M. Trainer, S. C. Wofsy, and D. D. Parrish. 2013. Quantifying sources of methane using light alkanes in the Los Angeles basin, California. J. Geophys. Res. 118:4974-4990. https://doi.org/10.1002/jgrd.50413.

Penn State College of Agricultural Sciences. 2017a. Holstein Growth Chart. The Pennsylvania State University, University Park. Accessed August 2017. https://extension.psu.edu/growth-charts-for -dairy-heifers\#section-1.

Penn State College of Agricultural Sciences. 2017b. Jersey growth chart. The Pennsylvania State University, University Park, PA Accessed August 2017. https://extension.psu.edu/growth-charts -for-dairy-heifers\#section-5.

Rahman, S., M. S. Borhan, and K. Swanson. 2013. Greenhouse gas emissions from beef cattle pen surfaces in North Dakota. Environ. Technol. 34:1239-1246. https://doi.org/10.1080/09593330.2012 .743598 .

Robinson, P. H., and D. Meyer. 2010. Total Mixed Ration (TMR) Sampling Protocol. University of California. Agriculture and Natural Resources-Publication 8413. ANR Communication Services, Davis, CA.

Roscioli, J. R., T. I. Yacovitch, C. Floerchinger, A. L. Mitchell, D. S. Tkacik, R. Subramanian, D. M. Martinez, T. L. Vaughn, L. Williams, D. Zimmerle, A. L. Robinson, S. C. Herndon, and A. J. Marchese. 2015. Measurements of methane emissions from natural gas gathering facilities and processing plants: measurement methods. Atmos. Meas. Tech. 8:2017-2035. https://doi.org/10.5194/ amt-8-2017-2015.

Shao, L., P. R. Griffiths, and A. B. Leytem. 2010. Advances in data processing for open-path fourier transform infrared spectrometry of greenhouse gases. Anal. Chem. 82:8027-8033. https://doi.org/ 10.1021/ac101711r.

Shindell, D., J. C. I. Kuylenstierna, E. Vignati, R. van Dingenen, M. Amann, Z. Klimont, S. C. Anenberg, N. Muller, G. JanssensMaenhout, F. Raes, J. Schwartz, G. Faluvegi, L. Pozzoli, K. Kupiainen, L. Höglund-Isaksson, L. Emberson, D. Streets, V. Ramanathan, K. Hicks, N. T. K. Oanh, G. Milly, M. Williams, V. Demkine, and D. Fowler. 2012. Simultaneously mitigating near-term climate change and improving human health and food security. Science 335:183-189. https://doi.org/10.1126/science.1210026.

State of California. 2016. Short-lived climate pollutants: Methane emissions: Dairy and livestock: Organic waste: Landfills. California Legislature, Sacramento.

Trousdell, J. F., S. A. Conley, A. Post, and I. C. Faloona. 2016. Observing entrainment mixing, photochemical ozone production, and regional methane emissions by aircraft using a simple mixed-layer framework. Atmos. Chem. Phys. 16:1615433-1615450. https://doi .org/10.5194/acp-16-15433-2016.

UC-IPM. 2017. California weather database. Agriculture and Natural Resources, University of California, Davis. Accessed May 2017. http://ipm.ucanr.edu/WEATHER/about_weather.html.

USDA-ERS. 2017. Milk cows and production by state and region (Annual). Accessed May 2017. https://www.ers.usda.gov/data -products/dairy-data/.

US EPA. 2017a. Annexes to the inventory of U.S. GHG emissions and sinks. U.S. Environmental Protection Agency. Inventory of U.S. Greenhouse gas emissions and sinks: 1990-2015. USEPA, Washington, DC, April 2017. Accessed September 2017. https:// www.epa.gov/sites/production/files/2017-02/documents/2017_all _annexes.pdf.

US EPA. 2017b. Inventory of U.S. greenhouse gases and sinks: 19902015. USEPA, Washington, DC, April 2017. Accessed September 2017. https://www.epa.gov/sites/production/files/2017-02/ documents/2017_complete_report.pdf.

VanderZaag, A. C., H. Baldé, A. Crolla, R. J. Gordon, N. M. Ngwabie, C. Wagner-Riddle, R. Desjardins, and J. D. MacDonald. 2018. Potential methane emission reductions for two manure treatment technologies. Environ. Technol. 39:851-858. https://doi.org/10 $.1080 / 09593330.2017 .1313317$.

Vanderzaag, A. C., T. K. Flesch, R. L. Desjardins, H. Baldé, and T. Wright. 2014. Measuring methane emissions from two dairy farms: Seasonal and manure-management effects. Agric. For. Meteorol. 194:259-267. https://doi.org/10.1016/j.agrformet.2014.02.003.

Vanderzaag, A. C., J. D. Macdonald, L. Evans, X. P. C. Vergé, and R. L. Desjardins. 2013. Towards an inventory of methane emissions from manure management that is responsive to changes on Canadian farms. Environ. Res. Lett. 8:035008. http://stacks.iop .org/ERL/8/035008.

Wecht, K. J., D. J. Jacob, C. Frankenberg, Z. Jiang, and D. R. Blake. 2014a. Mapping of North American methane emissions with high spatial resolution by inversion of SCIAMACHY satellite data. J. Geophys. Res. 119. https://doi.org/10.1002/2014JD021551.

Wecht, K. J., D. J. Jacob, M. P. Sulprizio, G. W. Santoni, S. C. Wofsy, R. Parker, H. Bösch, and J. Worden. 2014b. Spatially resolving methane emissions in California: Constraints from the CalNex aircraft campaign and from present (GOSAT, TES) and future (TROPOMI, geostationary) satellite observations. Atmos. Chem. Phys. 14:8173-8184. https://doi.org/10.5194/acp-14-8173-2014. 